\title{
Mathematical Description of a Newborn Human for Use in Dosimetry Calculations
}

\author{
J. M. L. Hwang \\ R. L. Shoup \\ J. W. Poston
}




\section{DISCLAIMER}

This report was prepared as an account of work sponsored by an agency of the United States Government. Neither the United States Government nor any agency Thereof, nor any of their employees, makes any warranty, express or implied, or assumes any legal liability or responsibility for the accuracy, completeness, or usefulness of any information, apparatus, product, or process disclosed, or represents that its use would not infringe privately owned rights. Reference herein to any specific commercial product, process, or service by trade name, trademark, manufacturer, or otherwise does not necessarily constitute or imply its endorsement, recommendation, or favoring by the United States Government or any agency thereof. The views and opinions of authors expressed herein do not necessarily state or reflect those of the United States Government or any agency thereof. 


\section{DISCLAIMER}

Portions of this document may be illegible in electronic image products. Images are produced from the best available original document. 
Printed in the United States of America. Available from National Technical Information Service

II.S. Lepartment of Commercc

5285 Port Royal Road, Springfield, Virginia 22161

Price: Printed Copy \$4.60, Microfiche \$2.25

$$
\$ 4.20
$$

This report was prepared as an account of work sponsored by the United States Government. Neither the United States nor the Energy Research and Development Administration/United States Nuclear Regulatory Commission, nor any of their employees, nor any of their contractors, subcontractors, or their employees, makes any warranty, express or implied, or assumes any legal liability or responsibility for the accuracy, completeness or usefulness of any information, apparatus, product or process disclosed, or represents that its use would not infringe privately owned rights. 
ORNL/TM-5453

\author{
Contract No. W-7405-eng-26 \\ HEALTH PHYSICS DIVISION
}

MATHEMATICAL DESCRIPTION OF A NEWBORN

HUMAN FOR USE IN DOSTMETRY CALCULATIONS

J. M. L. Hwang, R. L. Shoup, and J. W. Poston

\title{
SEPTEMBER 1976
}

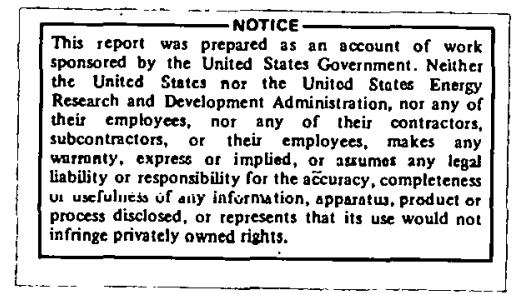

NOTICE This document contains information of a preliminary nature and was prepared primarily for internal use at the Uak Hiage National Laboratory. It is subject to revision or correction and therefore does not represerit a final report.

\author{
OAK RIDGE NATIONAL LABORATORY \\ Oak Ridge, Tennessee 37830 \\ operaled by \\ UNION CARBIDE CORPORATION \\ for the
}

ENERGY RESEARCH AND DEVELOPMENT ADMINISTRATION 


\section{THIS PAGE}

\section{WAS INTENTIONALLY}

LEFT BLANK 
TABLE OF CONTENTS

INTRODUCTION. . . . . . . . . . . . . . . . . I

DESCRIPTION OF THE NEWBORN MATHEMATICAL

PHANTOM. . . . . . . . . . . . . . . . . 7

Description of the Phantom and Organs

Exterior of the Phantom . . . . . . . . . . . 7

Organs . . . . . . . . . . . . . . . . 17

Gastrointestinal Tract and Contents. . . . . . . 27

REFERENCES. . . . . . . . . . . . . . . 42 
THIS PAGE

WAS INTENTIONALLY

LEFT BLANK 
LIST OF FIGURES

FIGURE

PAGE

1. X-Y Sectional Plot of Newborn Showing Upper Leg and Hip Region. . . . . . . . . . . . 8

2. X-Y Sectional Plot of Newborn Phantom Showing the Lower Abdomen Region. . . . . . . . . . . 9

3. X-Y Sectional Plots of the Newborn Phantom Showing the Upper Abdomen Region. . . . . . . 10

4. X-Y Sectional Plots of the Newborn Phantom Showing the Chest Region. . . . . . . . . . . . 11

5. X-Y Sectional Plots of the Newborn Phantom Showing the Head Region... . . . . . . . . 12

6. X-Z Sectional Plots of the Newborn Phantom . . . . . 13

7. X-Z Sectional Plots of the Newborn Phantom . . . . . 14

8. The Newborn Phantom - Gross Dimensions . . . . . . 15

9. Detailed View of Scapulae and Clavicles. . . . . . . . 21

10. Mathematical Models for the Bladder, Kidneys, Pancreas, Uterus, Spleen and Adrenals . . . . . . . 24

11. Mathematical Models for the Heart, Liver, Brain, and Lungs. . . . . . . . . . . . 26

12. Mathematical Model for the Gastrointestinal Tract. . . . . 31

13. Anterior Vich of the Principal Organs in the Head and Trunk of the Newborn Phantom . . . . . . . 32

14. Mathematical Models for the Thyroid, Testes, Ovaries and Thymus. . . . . . . . . . . . 35

15. Head Section of Phantom Illustrating Approximate Location of Salivary Glands . . . . . . . . . . 37

16. Sections of the Mathematical Thyroid at Varinus Heights for the Children Phantoms. Shaded Areas Represent the Thyroid ............ 40 


\section{LIST OF TABLES}

$\underline{\text { TABLE }}$

$\underline{\text { PAGE }}$

1. Summary - Physical Dimensions of the Newborn Phantom. . . . . . . . . . . . . 3

2. The Distribution of Active Bone Marrow in the Newborn Phantom .............. 4

3. Masses of Red and Yellow Marrow and Bone in the Newborn Phantom ............... 5

4. Summary of Organs for the Newborn Phantinm : , : . . . . . 6 
Estimating absorbed doses to children from external and internal radiation sources has become important to the nuclear industry and pediatric nuclear medicine. The Medical Physics and Internal Dosimetry Section at ORNL has recently completed the design of mathematical representations of children of ages newborn, 1-year, and 5-years old, which will be referred to as pediatric phantoms. The description of the 1-year and 5-year old phantoms were reported in ORNL-TM-5293, and the newborn is described in this report. Using these phantoms, relevant energy deposition data have been developed which establish a meaningful model for use in estimating radiation dose to children.

For several years, members of this Section have been developing the computer techniques to estimate fractions of $\mathrm{x}$-ray or gamma-ray energies absorbed in an adult phantom. This phantom is described in MIRD Pamphlet No. 5 and ORNL 5000 .

Until these pediatric phantoms were developed, geometrical shapes and similitude phantoms were used to represent children when dose estimates were calculated. Similitude phantoms, phantoms of ages younger than the adult, were obtained by shrinking each of the three regions of the adult phantom--head, trunk, and legs--by constant factors chosen to bc repreaentative of the particular age. All organs within each region were "shrunk" isotropically and changes in organ shape and location were ignored. Also, all the organs in the trunk, for instance, would have the same relative location in each phantom. These phantoms have been 
used extensively in the evaluation of the exposure of children even though it was recognized that these similitude phantoms represented children only to a first approximation.

However, the child is not merely an adult shrunk by a constant factor; the physiological geometry of a child is different from that of an adult. For example, (1) the weight of the head with respect to total body weight is greater for a child than an adult, this is taken into consideration for the similitude phantoms, (2) some internal organs, such as the thymus gland, are larger with respect to other major organs in the child, (3) the bone marrow of a newborn and a 1-year old is primarily red where in an adult the bone marrow is approximately $50 \%$ red and $50 \%$ yellow, and (4) the trunk of a child is more nearly circular than the adult trunk (which is best represented by an ellipse). Such factors as these precluded the possibility of making meaningful dose estimates to radiosensitive organs such as the gonads and red bone marrow.

The mathematical representation of the newborn was developed using data from andinical references and the ICRP Task Group on Referencc Man ${ }^{1}$ as a basis for gross phantom geometries and organ sizes, shapes, and weights. This phantom consists of head, trunk, and leg regions with a skeletal system and 24 internal organs. Tablos $1,2,3$, and 4 summarize the important.physical parameters. The reader is referred to ORNL-TM-5293, Chapter III, for a detailed discussion of the development of those data. The detailed mathematical description of this newborn phantom is discussed in the following section. 
TABLE 1

SUMMARY - PHYSICAL DIMENSIONS OF THE NEWBORN PHANTOM

\begin{tabular}{|c|c|c|}
\hline & & Newborn \\
\hline Wt: & Total Mass $(\mathrm{g})$ & 3964 \\
\hline S.G.: & Specific Gravity & 1.016 \\
\hline $\mathrm{V}:$ & Total Volume $\left(\mathrm{cm}^{2}\right)$ & 3901 \\
\hline $\mathrm{C}_{1}$ : & Circumference of Trunk (cm) & 37 \\
\hline $\mathrm{C}_{2}:$ & Circumference of Head $(\mathrm{cm})$ & .34 .2 \\
\hline$A_{1}:$ & Major Semiaxis (X-direction) of the trunk $(\mathrm{cm})$ & 6.2 \\
\hline $\mathrm{B}_{1}:$ & Minor Semiaxis ( $Y$-direction) of the trunk $(\mathrm{cm})$ & 5.6 \\
\hline $\mathrm{A}_{2}:$ & Major Semiaxis (Y-direction) of the head $(\mathrm{cm})$ & 5.6 \\
\hline $\mathrm{B}_{2}$ : & Minor Semiaxis (X-direction) of the head $(\mathrm{cm})$ & 5.3 \\
\hline $\mathrm{H}_{1}:$ & Length of Trunk (cm) & 21 \\
\hline $\mathrm{H}_{2}$ : & Length of Head $(\mathrm{cm})$ & 12.5 \\
\hline $\mathrm{H}_{3}:$ & Length of Legs $(\mathrm{cm})$ & 18.5 \\
\hline $\mathrm{H}:$ & Total Height $(\mathrm{cm})$ & 52 \\
\hline$r_{1}:$ & Upper Radius of Legs $(\mathrm{cm})$ & 3.1 \\
\hline $\mathbf{r}_{2}:$ & Lower Radius of Legs $(\mathrm{cm})$ & 1.2 \\
\hline$C:$ & Vertical Semiaxis of the Ellipsoid of Head $(\mathrm{cm})$ & 4.1 \\
\hline V: & Head $\left(\mathrm{cm}^{3}\right)$ & 1038 \\
\hline V: & Arms and Trunk $\left(\mathrm{cm}^{3}\right)$ & 2290 \\
\hline V: & Legs $\left(\mathrm{cm}^{3}\right)$ & 572 \\
\hline
\end{tabular}


TABLE 2

THE DISTRIBUTION OF ACTIVE BONE MARROW

IN THE NEWBORN PHANTOM

\begin{tabular}{lcc}
\hline Site & $\begin{array}{c}\text { \% Distribution of } \\
\text { Red Bone Marrow } \\
\text { in Skeleton }\end{array}$ & $\begin{array}{c}\text { Red Marrow Fraction of } \\
\text { Total Marrow (Red and } \\
\text { Yellow }\end{array}$ \\
\hline Arms the Bone
\end{tabular}

(Shleien, 1973) 
TABLE 3

MASSES OF RED AND YELLOW MARROW AND BONE IN THE NEWBORN PHANTOM

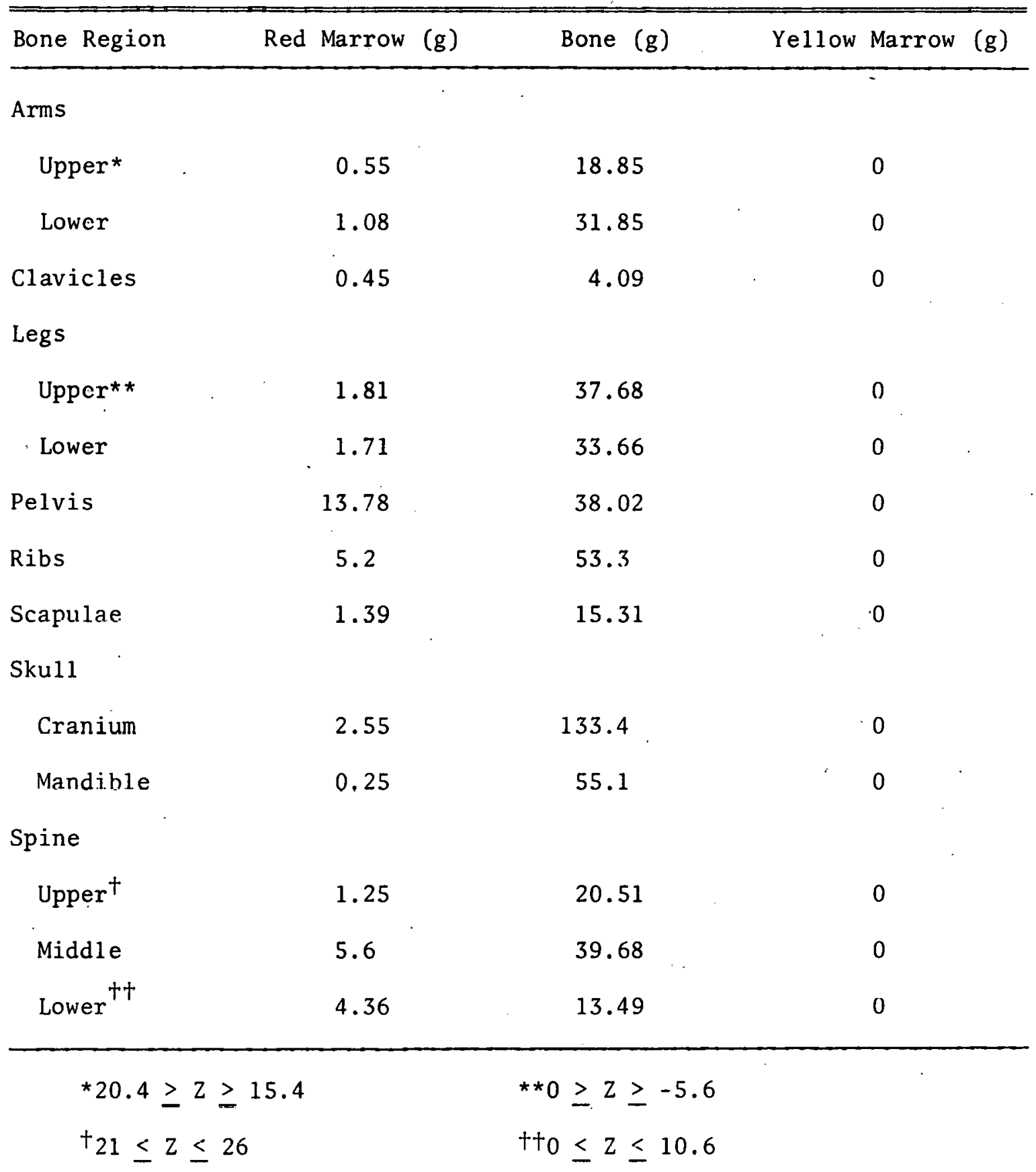


TABLE 4

SUMMARY OF ORGANS FOR THE NEWBORN PHANTOM

\begin{tabular}{lcc}
\hline \multicolumn{1}{c}{ Organs } & Mass $(\mathrm{g})$ & Volume $\left(\mathrm{cm}^{3}\right)$ \\
\hline Adrenals & 5.3 & 5.27 \\
Bl.adder & 2.67 & 2.66 \\
Brain & 372 & 369 \\
Gall Bladder & 0.72 & 0.72 \\
G.I. Tract & & 5.88 \\
Stuinach & 5.93 & 29.7 \\
S.I.* & 29.9 & 8.95 \\
U.L.I. & 9.02 & 8.19 \\
L.L.I. & 8.25 & 25 \\
Heart & 25.2 & 18.78 \\
Kidneys & 18.92 & 132.3 \\
Lungs & 39.7 & 111.9 \\
Liver & 112.7 & 0.30 \\
Ovaries & 0.303 & 2.56 \\
Pancreas & 2.58 & 6.12 \\
Salivary Glands & 6.28 & 229.3 \\
Skin & 231 & 8.76 \\
Spleen & 8.83 & 3801.36 \\
Skel Ation & 532.2 & 0 \\
Red Bonc Marrow & 40.0 & 11.46 \\
Yellow Bone Marrow & 0 & 0.96 \\
Thymus & 11.54 & 0.83 \\
Thyroid & 0.97 & 2.75 \\
Testes & 0.84 & \\
Uterus & 2.77 & \\
& & \\
\hline
\end{tabular}

*Includes Smal1 Intestine contents. 
The mathematical description of this phantom has been coded into Fortran computer language for use with a cross-section plotting routine and with a photon transport code.

Horizontal and vertical chest cross sections of this phantom are shown in Figures $1-7$.

DESCRIPTION OF THE NEWBORN MATHEMATICAI, PHANTOM

The phantom consists of three types of tissue-lung tissue, skeletal tissue and soft tissue. The skeletal system represents the total content of the intact skeleton and includes both bone and bone marrow. The marrow is considered to be homogeneously distributed in the skeleton. The densities of the skeletal region (bone plus marrow), lungs and the remaining soft tissue of the phantom are approximately $1.4,0.3$ and $1.0074 \mathrm{~g} / \mathrm{cm}^{3}$, respectively.

Description of the Phantom and Organs Exterior of the Phantom

The body of the phantom is represented as erect with the positive $Z$-axis directed upward toward the head. The $X$-axis is directed to the phantom's left (the reader's right in Figure 8), and the $Y$-axis is directed lowald the postcrior or back of the phantom. The origin of these Cartesian coordinates is at the center of the hase of the "trunk" section of the phantom and the axes are calibrated in centimeters.

The "trunk" is a solid elliptical cylinder specified by

$$
\left(\frac{X}{6.2}\right)^{2}+\left(\frac{Y}{5.6}\right)^{2} \leqq 1,
$$



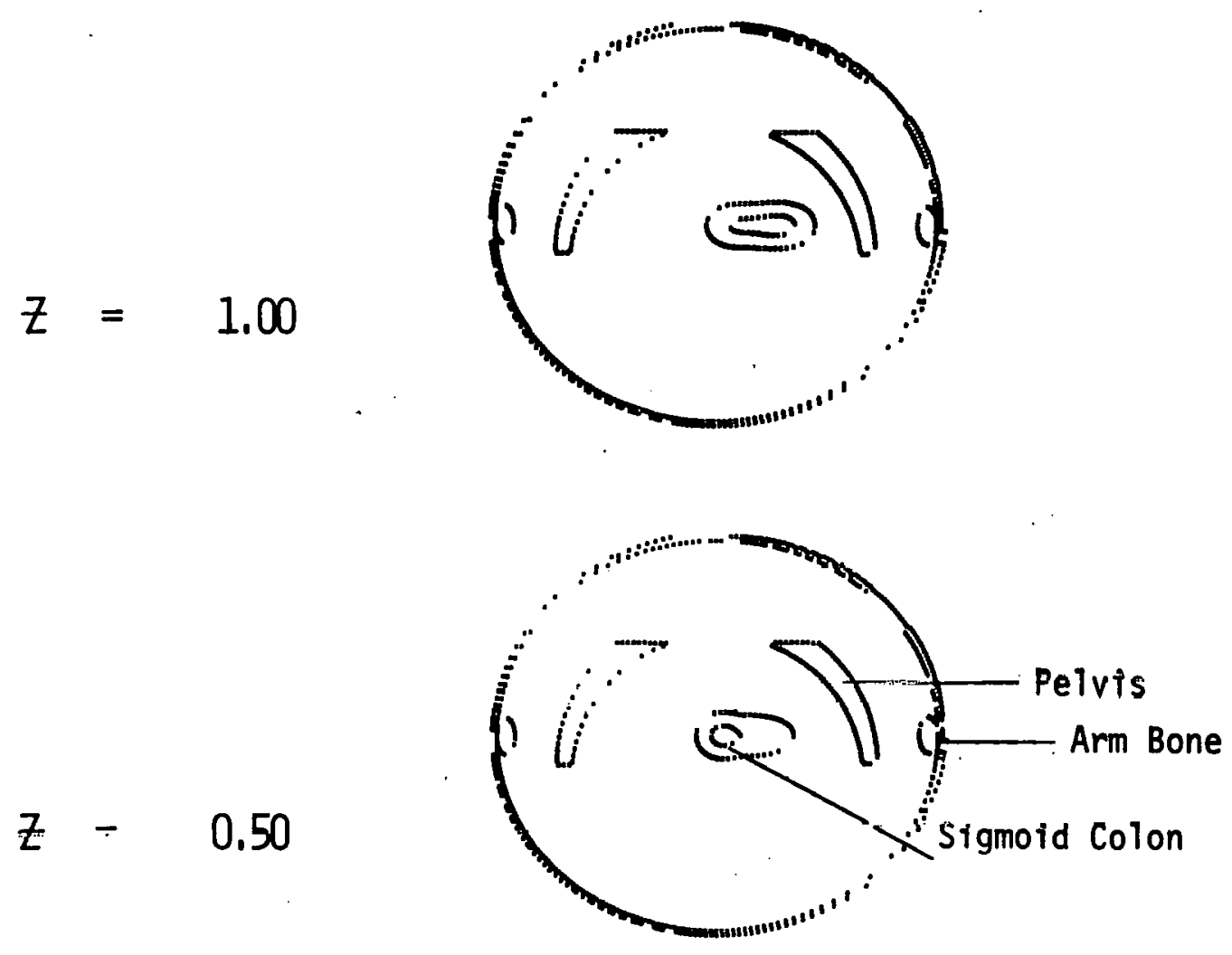

$z=0.0$

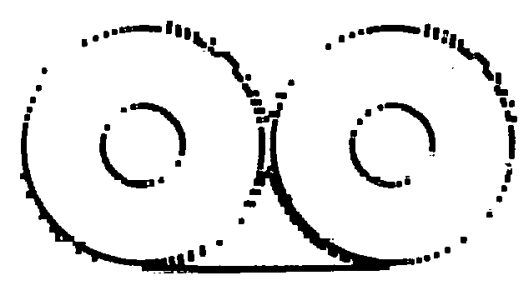

$z=-0.50$

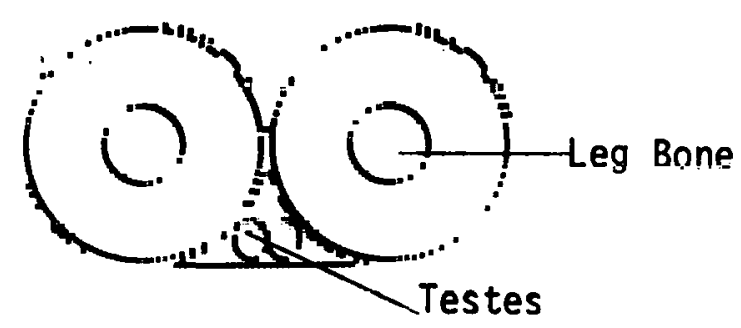

FIGURE 1. X-Y Sectional Plot of Newborn Showing Upper Leg and Hip Region 
$z=6.00$

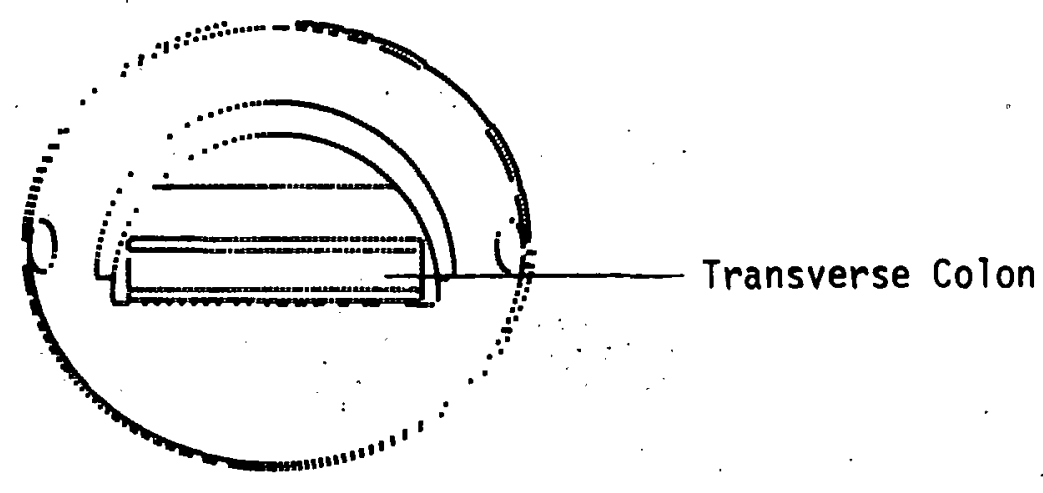

$z=5.00$

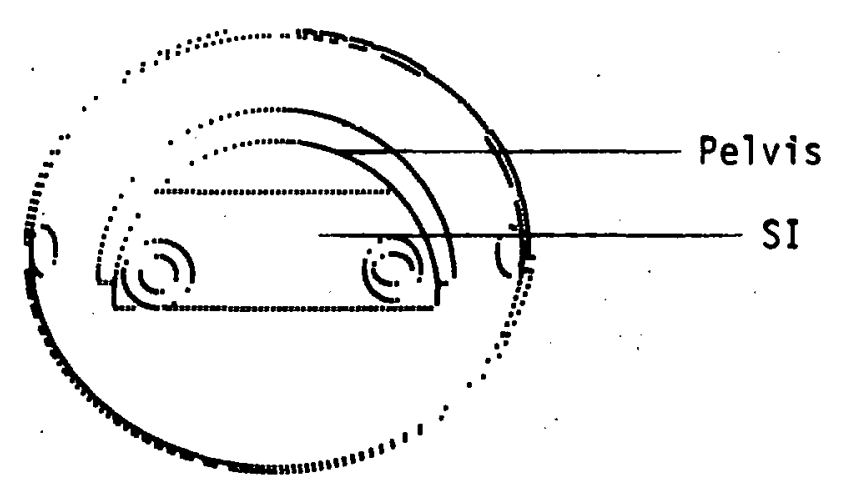

$z=4.50$

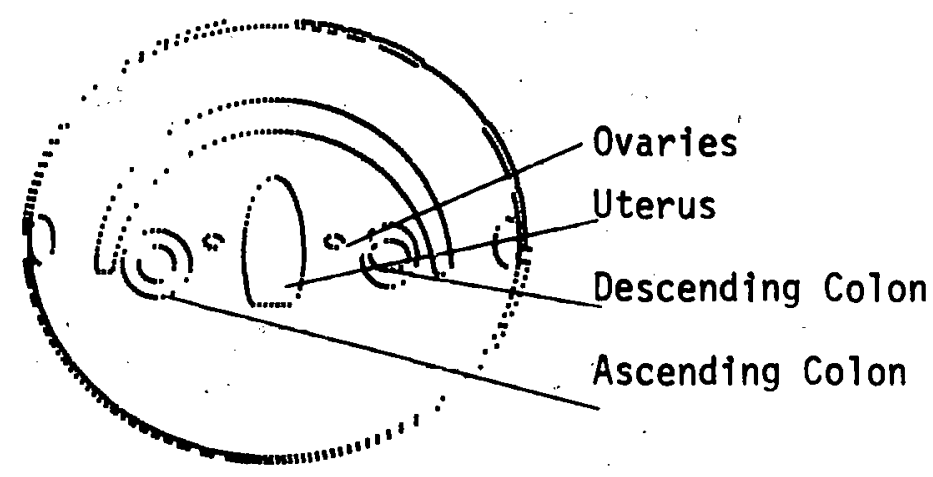

$z=2.50$

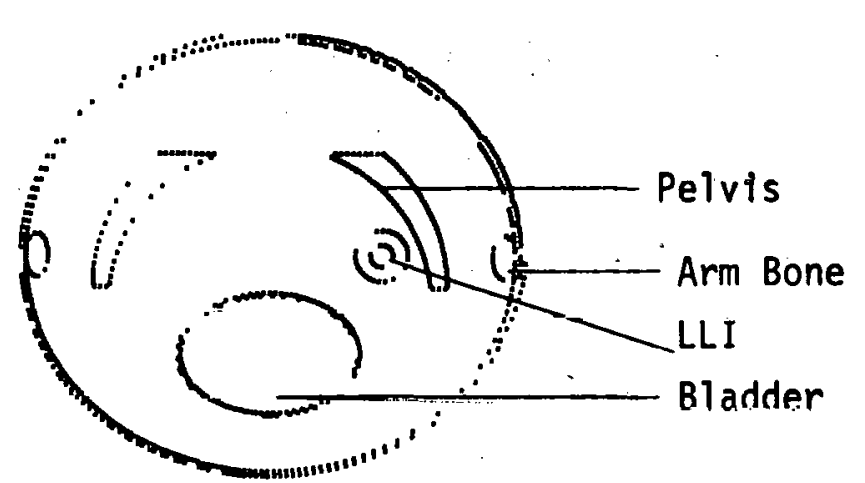

FIGURE 2. X-Y Sectional Plot of Newborn Phantom Showing the Lower Abdomen Region 


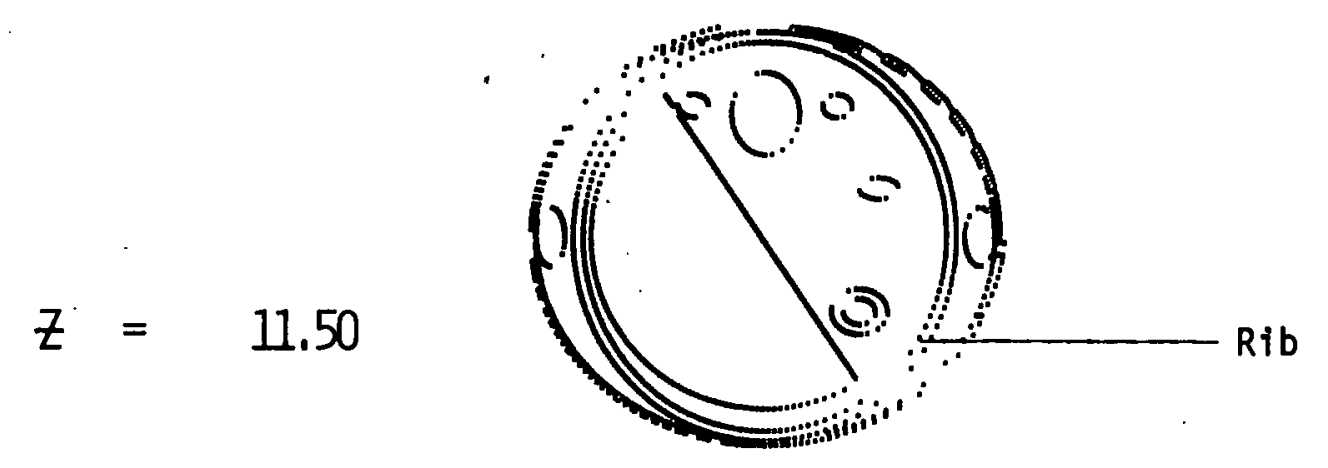

$z=9.50$
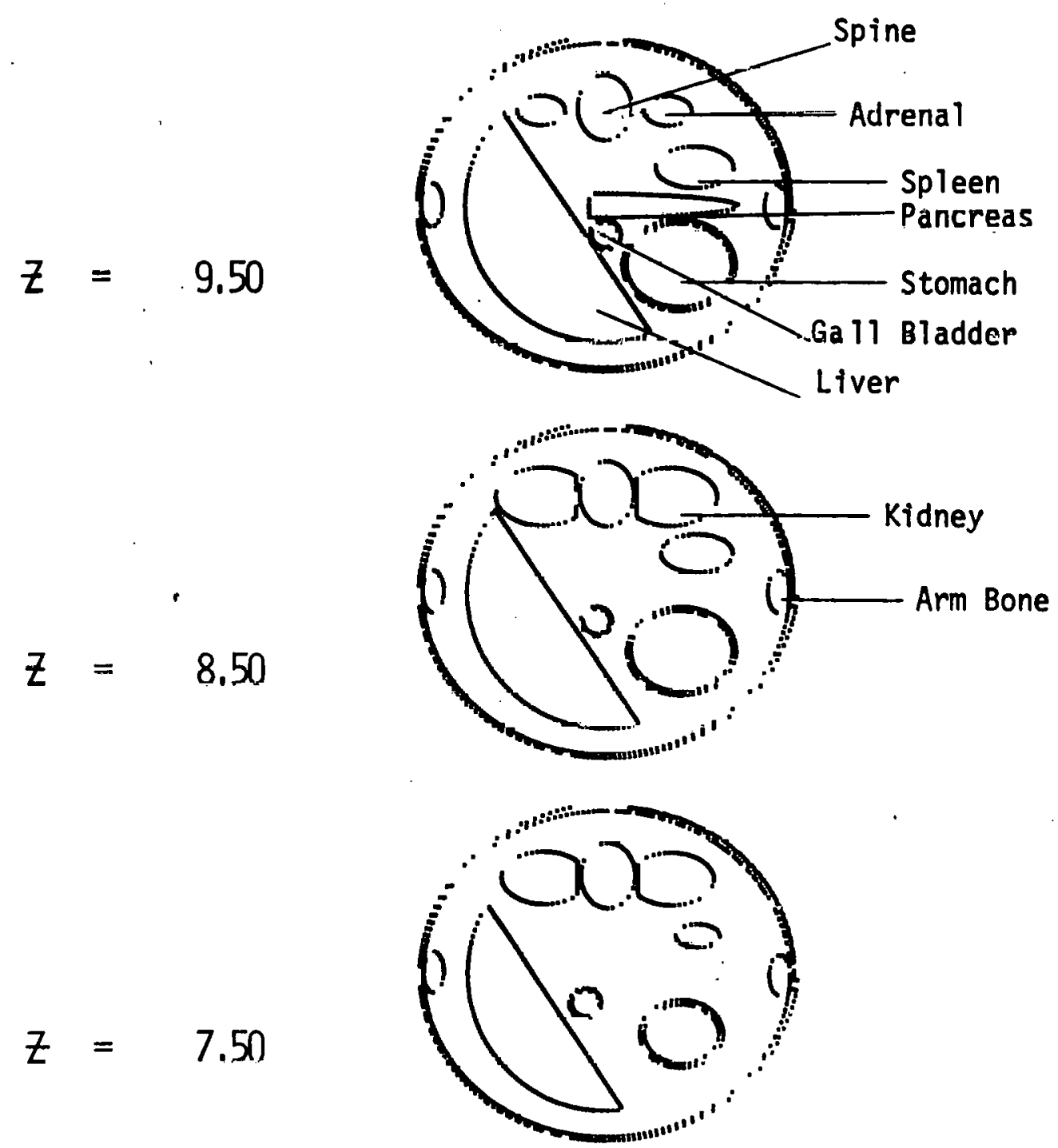

FIGURE 3. X-Y Sectional Plots of the Newborn Phantom Showing the Upper Abdomen Region 

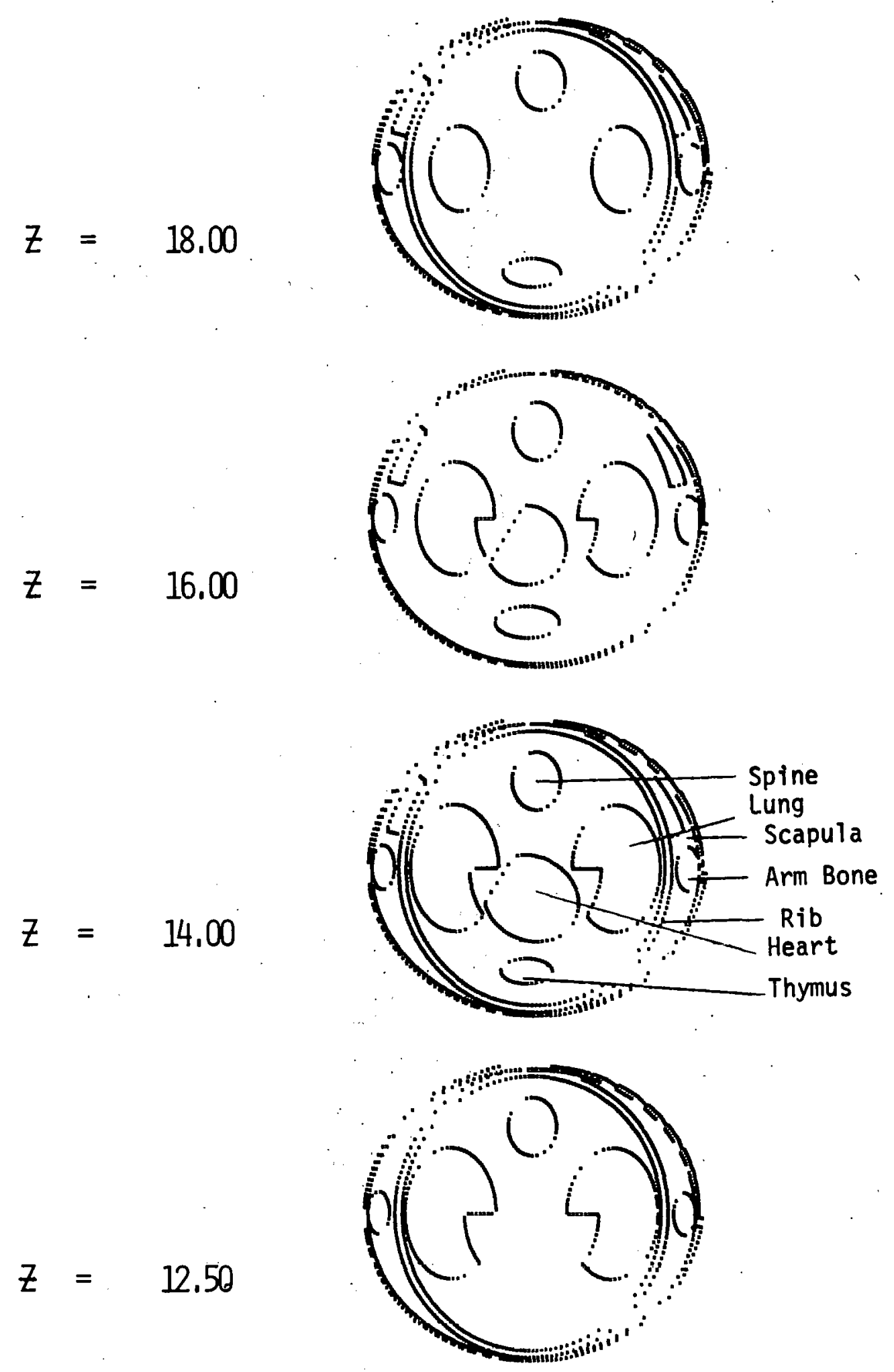

FIGURE 4. X-Y Sectional Plots of the Newborn Phantom Showing the Chest Region 

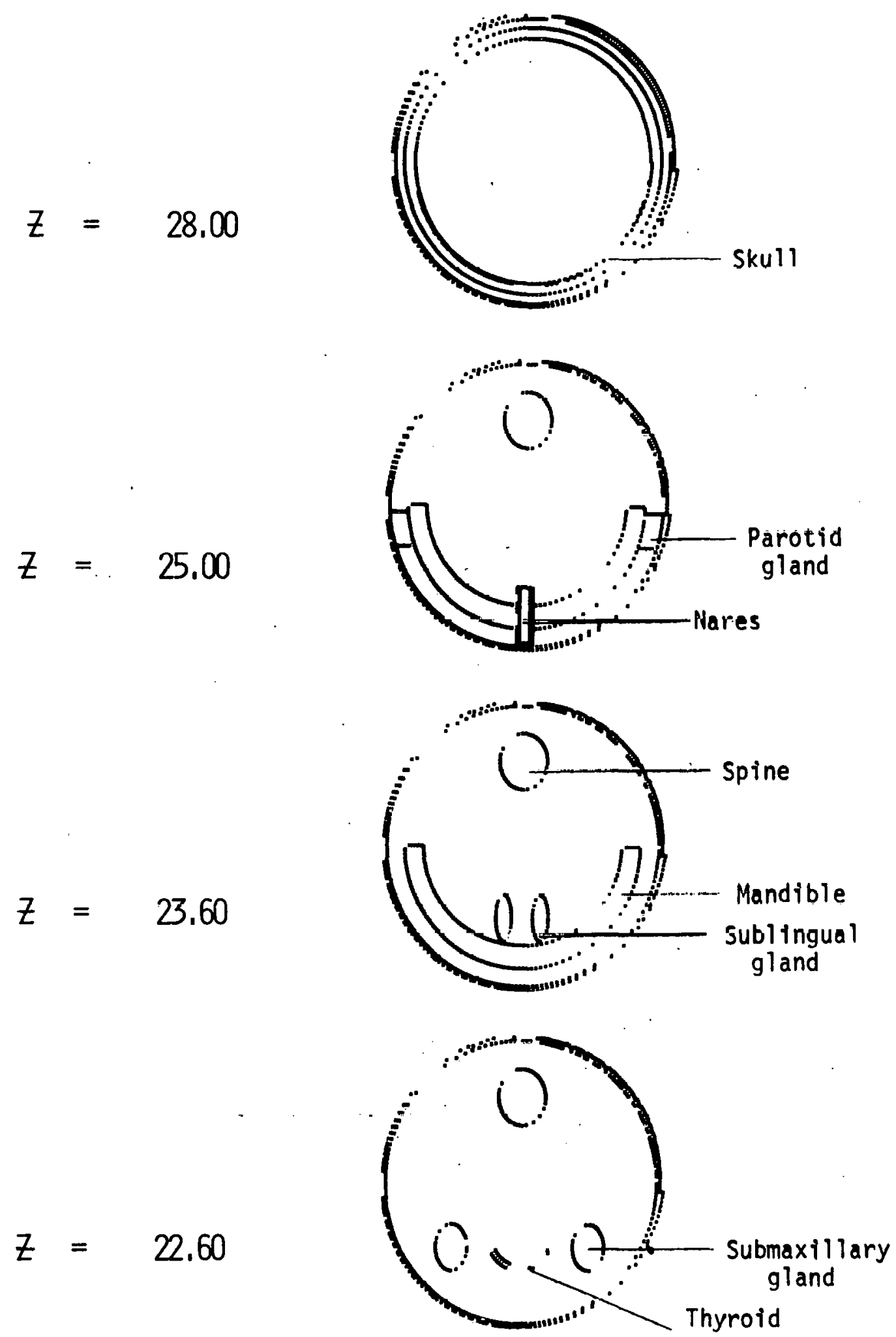

FIGURE 5. X-Y Sectional Plots of the Newborn Phantom Showing the Head Region 

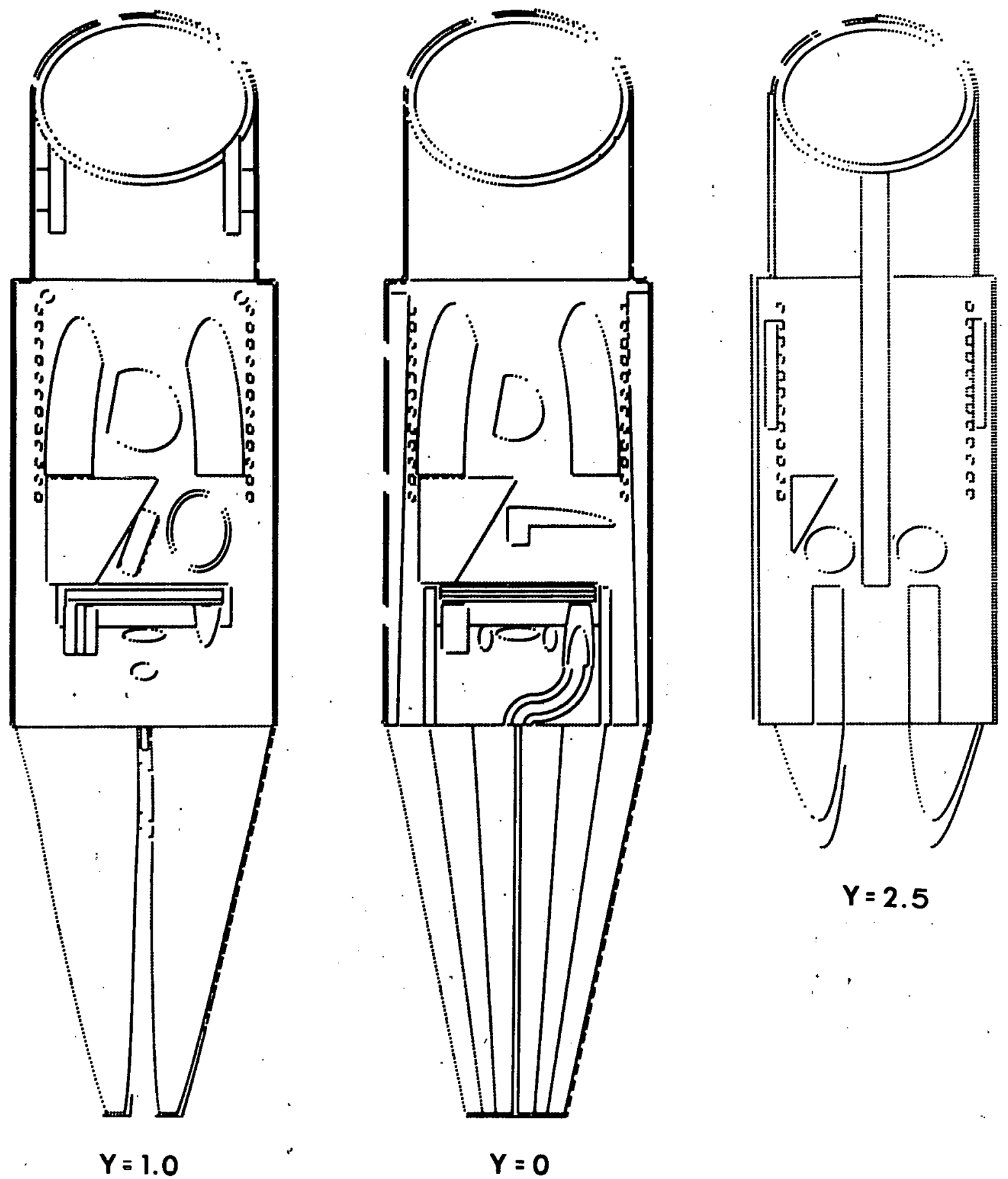

$Y=1.0$

$\cdot$

FICURE 6. $\mathrm{X}-\mathrm{Z}$ Sectional Plots of the Newborn Phantom 

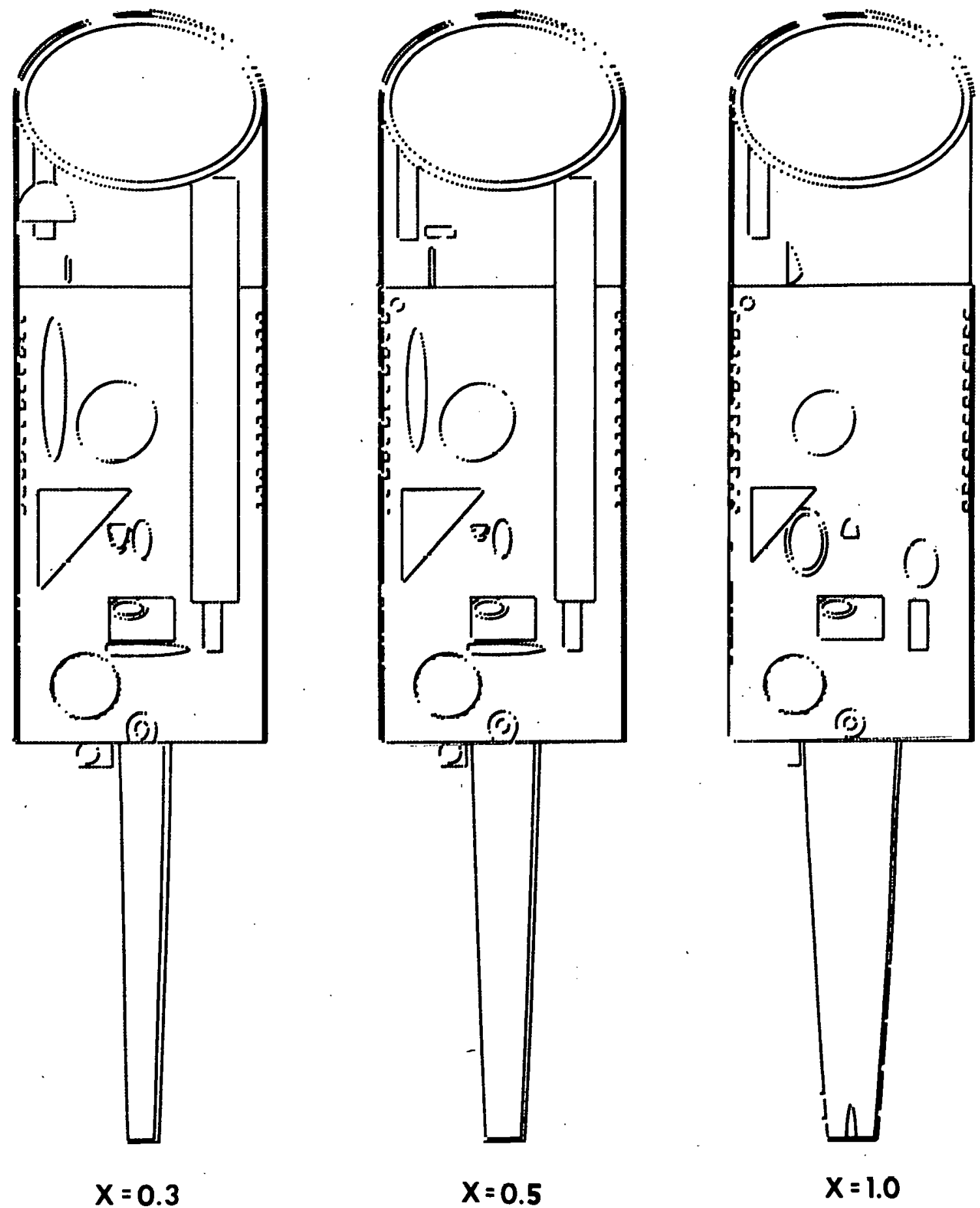

FIGURE 7. X-Z Sectional Plots of the Newborn Phantom 


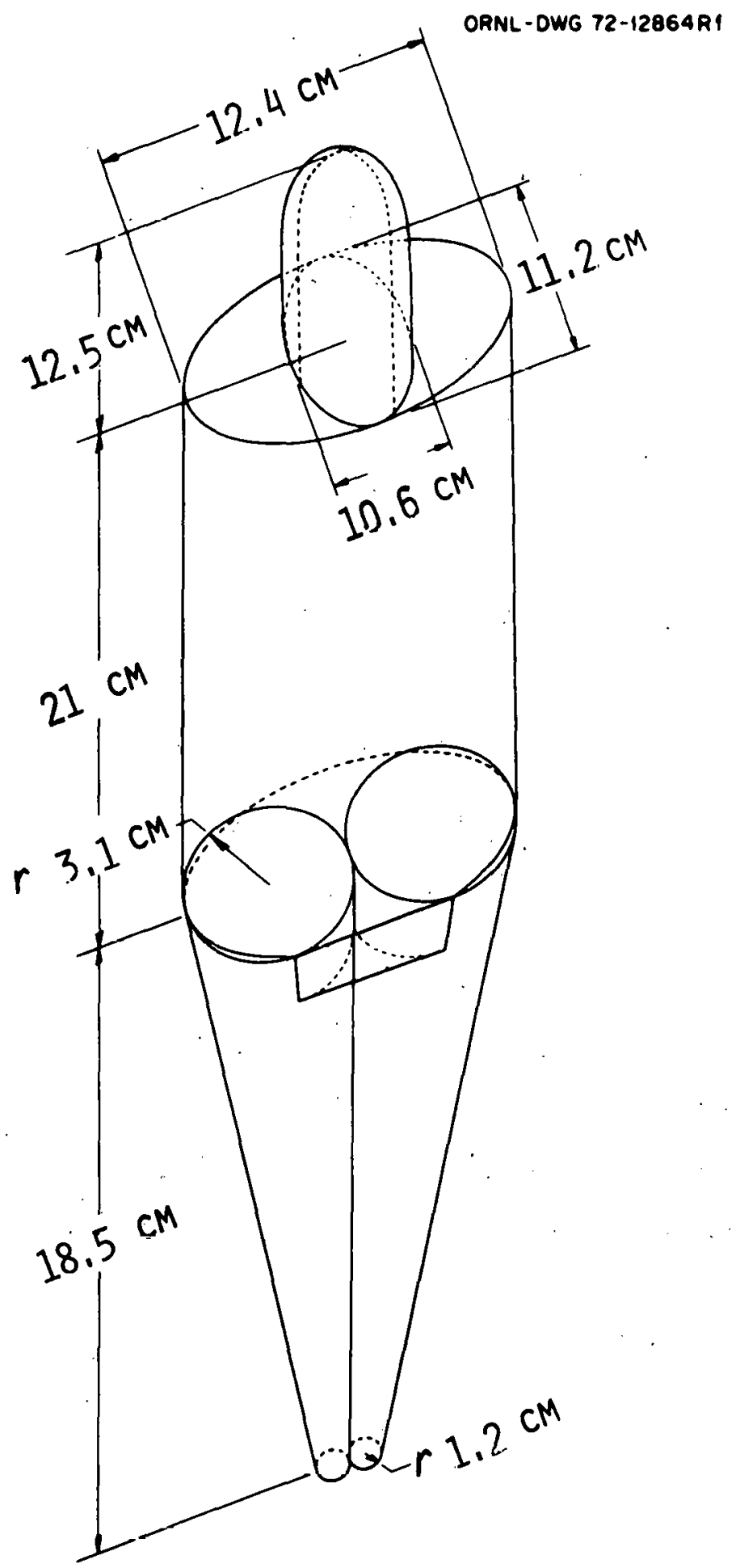

FIGURE 8. The Newborn Phantom - Gross Dimensions 
and

$$
0 \leq z \leq 21
$$

where the "trunk" includes the arms as well as the pelvic and hip bones from the point where the separation of the legs begins. The volume of the trunk section is $2,290.6 \mathrm{~cm}^{3}$, and the mass, as will be discussed later, is $2,283 \mathrm{~g}$.

The head section is a right elliptical cylinder topped by half an ellipsoid. The locus is specified hy:

$$
\begin{gathered}
\left(\frac{X}{5.3}\right)^{2}+\left(\frac{Y}{5.6}\right)^{2} \leq 1, \\
21 \leq z \leq 29.4 \\
\left(\frac{X}{5.3}\right)^{2}+\left(\frac{Y}{5.6}\right)^{2}+\left(\frac{Z-29.4}{4.1}\right)^{2} \leq 1,
\end{gathered}
$$

and

$$
29.4 \leq z \leq 33.5 \text {. }
$$

The total volume is $1,038 \mathrm{~cm}^{3}$, and the mass is $1,105 \mathrm{~g}$.

The leg region of the phantom consists of the frustrums of two circular cones specified by

$$
X^{2}+Y^{2} \leqq \pm X\left(6.2+\frac{Z}{4.868}\right)
$$

and

$$
-18.5 \leq 2 \leq 0
$$


where the plus sign defines the left leg and the minus sign the right. The total volume of both legs is $572.3 \mathrm{~cm}^{3}$, and the mass is $605.9 \mathrm{~g}$. The leg region does not join smoothly to the trunk region, since the legs protrude slightly beyond the ellipse defining the trunk in the plane $Z=0$.

The genitalia region (male) of the phantom consists of the region specified by

$$
\begin{gathered}
-1.13 \leq Z \leq 0, \\
-\left(3.1+\frac{Z}{9.736}\right) \leq X \leq\left(3.1+\frac{Z}{9.736}\right), \\
-\left(3.1+\frac{Z}{9.736}\right) \leq Y \leq 0
\end{gathered}
$$

and

$$
\left(X \pm\left(3.1+\frac{Z}{9.736}\right)\right)^{2}+Y^{2} \geq\left(3.1+\frac{Z}{9.736}\right)^{2},
$$

This last inequality must hold for either choice of sign, i.e., the genitalia region lies between but outside both legs. The genitalia region has a volume of $4.48 \mathrm{~cm}^{3}$ and a mass of $4.52 \mathrm{~g}$.

\section{Organs}

Skeletal System. The skeletal system consists of the thirteen parts described below, and in Monte Carlo photon transport calculation absorbed fractions are recorded separately for each part as well as for the total skeleton.

Leg Bones. Each leg bone is the frustrum of a circular cone. The expression for the left leg bone is 


$$
\left(X-3.1-\frac{1.9}{18.37} Z\right)^{2}+Y^{2} \leq\left(1.0+\frac{0.7}{18.37} Z\right)^{2}
$$

and

$$
-18.37 \leq z \leq 0
$$

The volume of both bones is $53.5 \mathrm{~cm}^{3}$ and the mass is $74.9 \mathrm{~g}$.

Arm Bones. Each arm bone is the frustrum of an elliptical cone.

The left one is defined by

$$
\left[\frac{(0.5 / 40.8)(Z-20.4)+(X-5.57)}{0.5}\right]^{2}+\frac{Y}{1.0} \leq\left[\frac{40.8+(Z-20.4)}{40.8}\right]^{2}
$$

and

$$
0 \leq z \leq 20.4
$$

The volume of both arm bones is $37.4 \mathrm{~cm}^{3}$ and the mass is $52.3 \mathrm{~g}$.

Pelvis. The pelvis is a portion of the volume between two nunconcentric circular cylinders described by

$$
\begin{gathered}
X^{2}+(Y+0.8)^{2} \leq(4.4)^{2} \\
X^{2}+(Y+1.2)^{2} \geq(4.0)^{2} \\
Y+0.8 \geq 0 \\
0 \leq Z \leq 6.5 \\
Y \leq 2.3 \text { if } Z \leq 4.2 .
\end{gathered}
$$

Its volume is $37 \mathrm{~cm}^{3}$, and its mass is $51.8 \mathrm{~g}$.

Spine. The spine is an elliptical cylinder given by 


$$
\left(\frac{x}{0.9}\right)^{2}+\left(\frac{y-3.3}{1.1}\right)^{2} \leq 1
$$

and

$$
6.5 \leq \mathrm{z} \leq 26
$$

and has a volume of $60.6 \mathrm{~cm}^{3}$ and a mass of $84.9 \mathrm{~g}$. It is divided into three portions-an upper, middle, and lower-in which absorbed fractions are estimated separately. These divisions are formed by the planes $Z=21$ and $Z=10.6$ :

Rib Cage. The rib volume is a series of bands between two concentric, right-vertical, elliptical cylinders. This region is sliced by a series of equispread horizontal planes into slabs, every other elliptical slice being a rib. The equations describing the ribs are:

$$
\begin{gathered}
\left(\frac{X}{5.07}\right)^{2}+\left(\frac{Y}{5.47}\right)^{2} \leq 1 \\
\left(\frac{X}{4.8}\right)^{2}+\left(\frac{Y}{5.2}\right)^{2} \geq 1 \\
10.6 \leq Z \leq 19.8 \\
\text { Integer }\left(\frac{Z-10.6}{0.4}\right) \text { is even. }
\end{gathered}
$$

The total rib volume is $41: 8 \mathrm{~cm}^{3}$ and the mass is $58.5 \mathrm{~g}$.

Clavicles. The clavicles are represented as two portions of a torus which lie aiong the circular are $X^{2}+(Y+0.3)^{2}=(4.5)^{2}, Z=20.2$, and has a smaller radius of $0.2884 \mathrm{~cm}$. The clavicles include only the portion of the torus between the planes $-0.3-Y=|X| \cot \theta$ where $\theta=6^{\circ}$ 
and $85^{\circ}$. The absolute value sign on $X$ allows for both a right and a left clavicle. The volume of both clavicles is $3.24 \mathrm{~cm}^{3}$, and the mass is about $4.54 \mathrm{~g}$. The equation can be reduced to the form

$$
(Z-20.2)^{2}+\left(4.5-\sqrt{X^{2}+(Y+0.3)^{2}}\right)^{2} \leq(0.2884)^{2}
$$

and

$$
\begin{gathered}
.0875 \leq \frac{-0.3-Y}{|X|} \leq 9.514, \\
Y \leq 0 .
\end{gathered}
$$

The clavicles lie slightly inside the elliptical cylinder defining the rib cage and just above the top rib. They are shown schematically in Figure 9.

Scapulae. The scapulae extend from $Z=19 \mathrm{~cm}$ to $Z=13.9 \mathrm{~cm}$ and lie between two ellipticàl cylinders:

$$
\left(\frac{X}{5.07}\right)^{2}+\left(\frac{Y}{5.47}\right)^{2}=1 \text { (outer surface of ribs) }
$$

and

$$
\left(\frac{X}{5.7}\right)^{2}+\left(\frac{Y}{5.47}\right)^{2}=1
$$

Although the lower portion of the scapula is somewhat smaller than the upper, this distinction is ignored here, and the left scapula will occupy all the above spare hetween the planes $Y=0.25 x$ and $Y-0.80 X$.

Thus the test for point $(X, Y, Z)$ to be in the left scapula it must satisfy the following: 


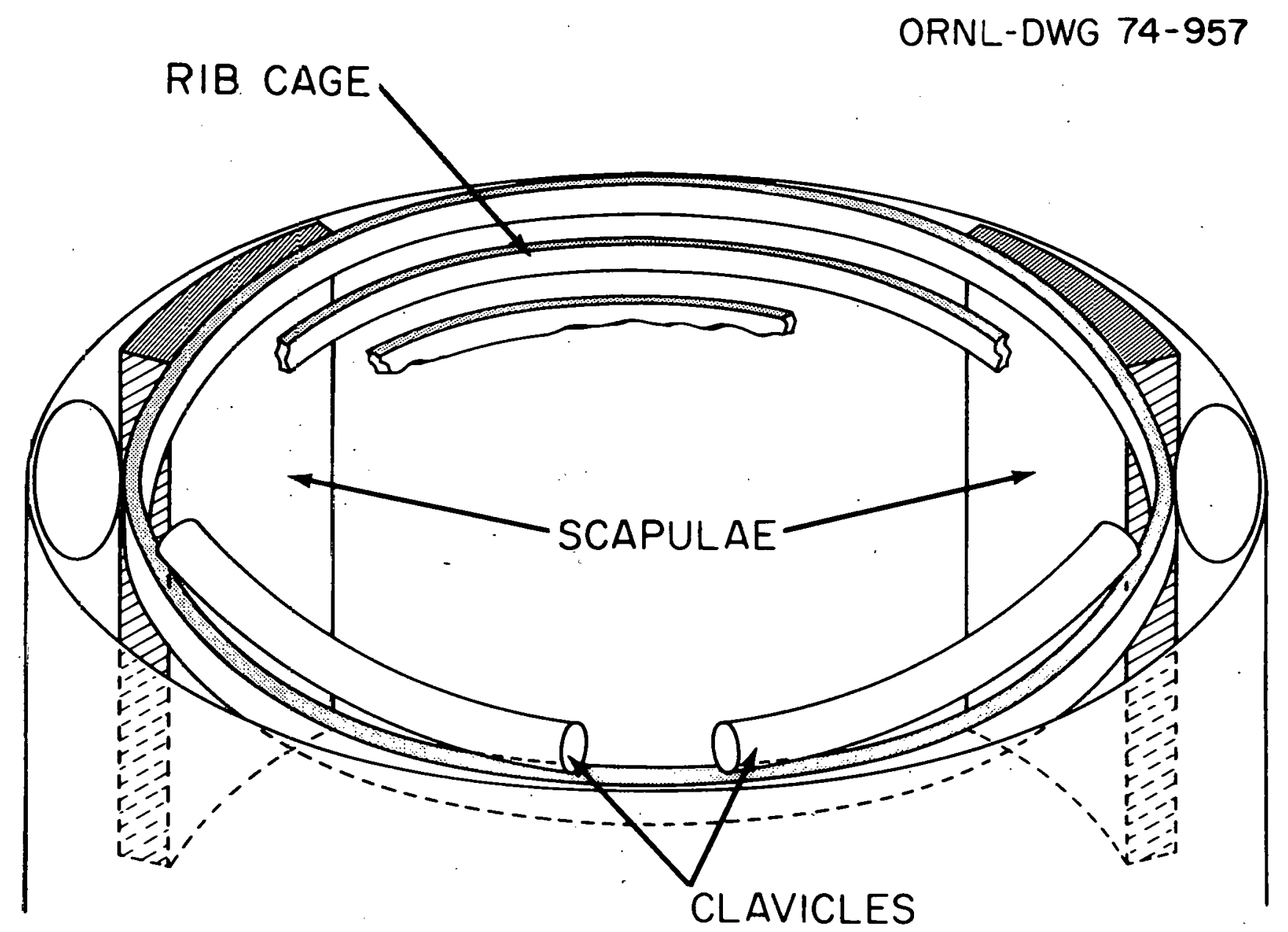

FIGURE 9. Detailed View of Scapulae and Clavicles 


$$
\begin{gathered}
13.9 \leq Z \leq 19, \\
\left(\frac{X}{5.7}\right)^{2}+\left(\frac{Y}{5.47}\right)^{2} \leq 1, \\
\left(\frac{X}{5.07}\right)^{2}+\left(\frac{Y}{5.47}\right)^{2}>1, \\
Y>0, \quad 0.25<Y / X<0.80 .
\end{gathered}
$$

For the right scapula, only the last inequality needs to be replaced by

$$
0.25<Y /-X<0.80
$$

For both scapulae, one uses

$$
0.25<Y /|X|<0.80
$$

where the other four inequalities remain unaltered.

The volume of both scapulae is $11.9 \mathrm{~cm}^{3}$ and the mass is $16.7 \mathrm{~g}$. Thc scapulae, as so defined, do not intersect the arm bones or the ribs or other designated organs of the phantom. The scapulae are included in Figure 9 .

Mandible. The mandible is a portion of the volume between. two concentric elliptical cylinders. The upper rear portion of these cylinders intersect the cranium and this volume is subtracted off. The mandible is described by:

$$
\left(\frac{X}{4.47}\right)^{2}+\left(\frac{Y}{4.77}\right)^{2} \leq 1
$$




$$
\begin{gathered}
\left(\frac{X}{3.77}\right)^{2}+\left(\frac{Y}{3.87}\right)^{2} \leq 1 \\
Y \leq 0 \\
23.2 \leq Z \leq 28.2 .
\end{gathered}
$$

and

$$
\left(\frac{X}{5.17}\right)^{2}+\left(\frac{Y}{5.47}\right)^{2}+\left(\frac{Z-29.4}{3.97}\right)^{2} \geq 1 .
$$

The total volume of the mandible $39.3 \mathrm{~cm}^{3}$, with a mass of $55.1 \mathrm{~g}$.

Cranium. The cranium is the volume between two concentric ellipsoids defined by

$$
\begin{aligned}
& \left(\frac{X}{5.17}\right)^{2}+\left(\frac{Y}{5.47}\right)^{2}+\left(\frac{Z-29.4}{3.97}\right)^{2} \leq 1 \\
& \left(\frac{X}{4.8}\right)^{2}+\left(\frac{Y}{5.1}\right)^{2}+\left(\frac{Z-29.4}{3.6}\right)^{2} \geq 1 .
\end{aligned}
$$

The total volume of the cranium is $95.3 \mathrm{~cm}^{3}$, and the mass is $133.4 \mathrm{~g}$.

Adrenals. Each adrenal is half an ellipsoid atop a kidney. The left adrenal is given by

$$
\left(\frac{X-1.9}{0.9}\right)^{2}+\left(\frac{Y-3.5}{0.7}\right)^{2}+\left(\frac{Z-9.7}{2}\right)^{2} \leq 1
$$

and

$$
\mathrm{Z} \geq 9.7
$$

The volume of both adrenals is $5.27 \mathrm{~cm}^{3}$ (Figure 10), and the mass is $5.3 \mathrm{~g}$. 


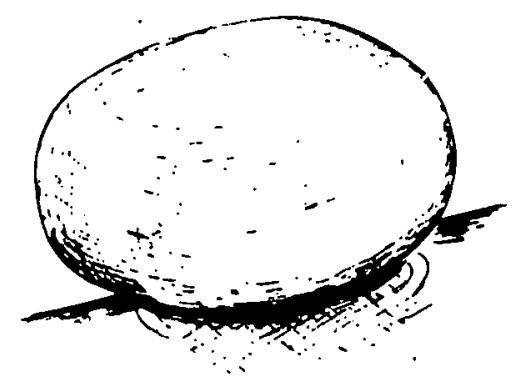

BLADDER

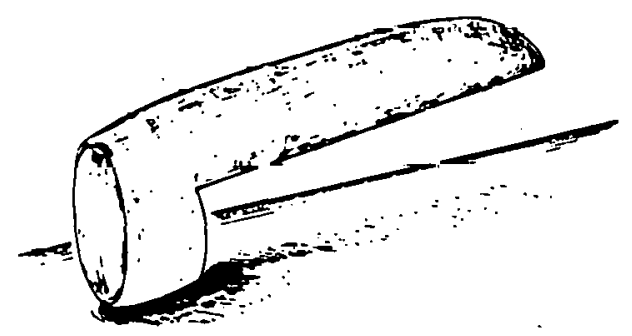

PANCREAS

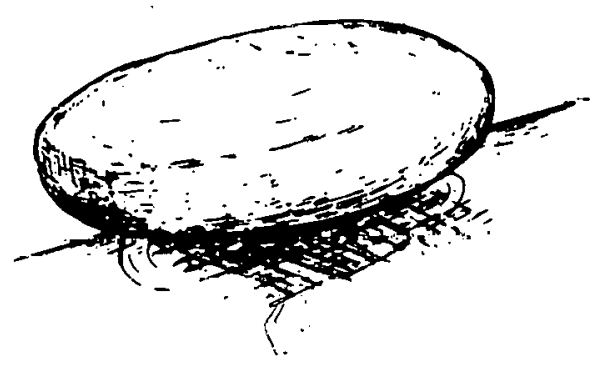

SPIEEN

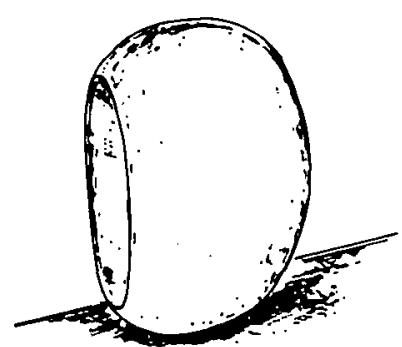

KIDNEY

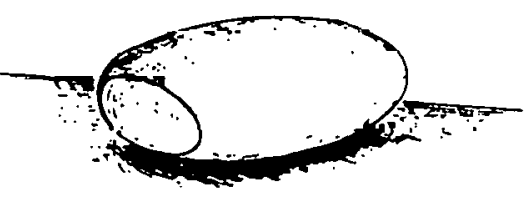

UTERUS

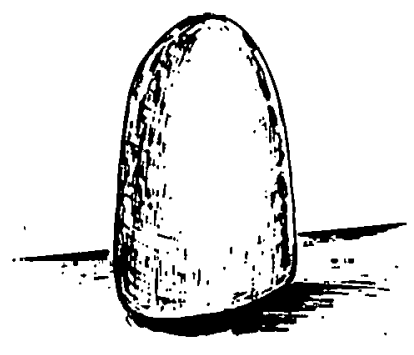

ADRENAL

FIGURE 10.. Mathematical Models for the Bladder, Kidneys, Pancreas, Uterus, Spleen and Adrenals 
Urinary Bladder and Contents. The bladder is an ellipsoid and is defined by the inequalities:

$$
\begin{aligned}
& \left(\frac{X}{2.27}\right)^{2}+\left(\frac{Y+2.5}{1.55}\right)^{2}+\left(\frac{Z-2.6}{1.55}\right)^{2} \leq 1 \\
& \left(\frac{X}{2.2}\right)^{2}+\left(\frac{Y+2.5}{1.48}\right)^{2}+\left(\frac{Z-2.6}{1.48}\right)^{2} \geq 1 .
\end{aligned}
$$

The volume is $2.66 \mathrm{~cm}^{3}$, and the mass is $2.67 \mathrm{~g}$. The contents have a volume of $20.2 \mathrm{~cm}^{3}$ and a mass of $20.3 \mathrm{~g}$. This represents a moderately fu11 bladder.

Dose to the bladder wall from a photon emitter present in the urine will vary greatly, depending on the degree of filling even for the same concentration or amount of activity present. The specific absorbed fraction, $\Phi$ (bladder $\leftarrow$ content), will vary by approximately an order of magnitude. $^{2}$ [Thus the user of these data should be aware that the values tabulated are only appropriate for one size of bladder. The difference in $\Phi$, or dose rate, to the bladder walls of different sizes from other source organs outside the bladder is generally small.] The bladder is shown in Figure 10.

Brain. The brain is an ellipsoid given by

$$
\left(\frac{X}{4.8}\right)^{2}+\left(\frac{Y}{5.1}\right)^{2}+\left(\frac{Z-29.4}{3.6}\right)^{2} \leq 1
$$

and the volume is $369 \mathrm{~cm}^{3}$ and the mass is $372 \mathrm{~g}$ (Figure 11). 

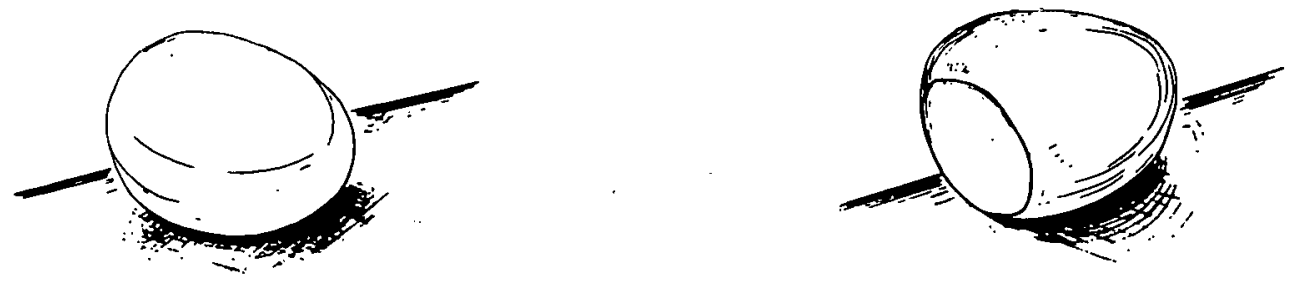

HEART

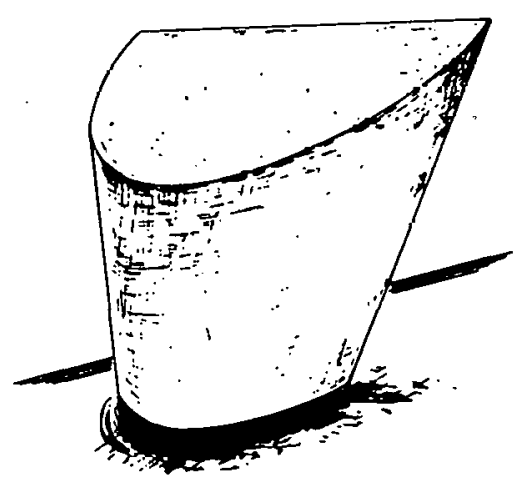

I IVER
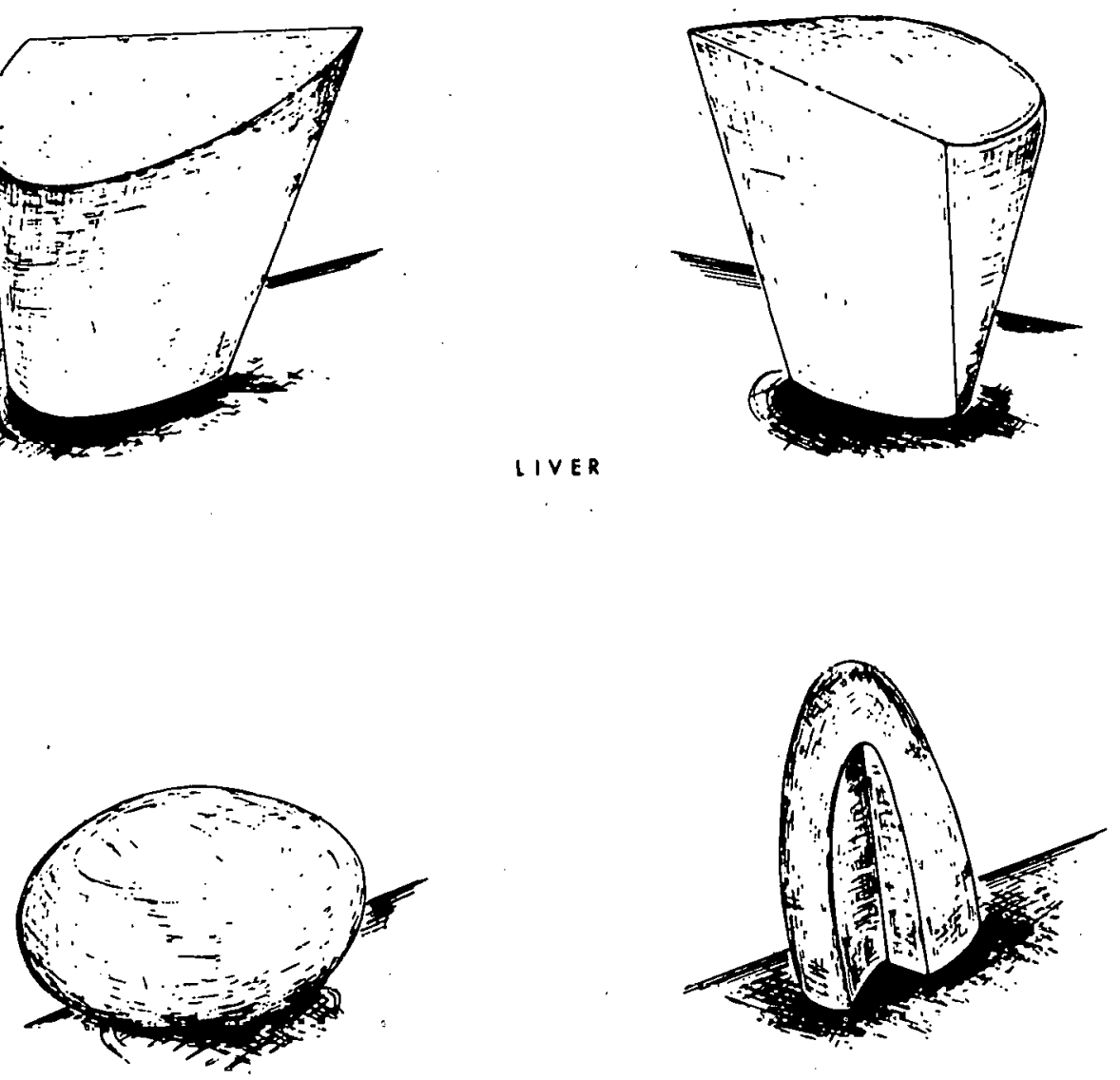

BRAIN

IUNG

FIGURE 11. Mathematical Model for the Heart, Liver, Brain and Lungs 
Gastrointestinal Tract and Contents

Stomach (S). The stomach is represented as the mass between two ellipsoids

$$
\left(\frac{X-2.5}{1.9}\right)^{2}+\left(\frac{Y+2}{1.55}\right)^{2}+\left(\frac{Z-9.2}{2.5}\right)^{2} \leq 1
$$

and

$$
\left(\frac{X-2.5}{1.77}\right)^{2}+\left(\frac{Y+2}{1.42}\right)^{2}+\left(\frac{Z-9.2}{2.37}\right)^{2} \geq 1
$$

The volume is $5.88 \mathrm{~cm}^{3}$, and the mass is $5.93 \mathrm{~g}$. The contents have a volume of $24.9 \mathrm{~cm}^{3}$ and a mass of $25 \mathrm{~g}$. The thickness of the stomach wall is about $0.13 \mathrm{~cm}$.

The stomach represented here is a "full" stomach, and the average dose rate, even for the same activity present, probably varies greatly depending on the degree of extension of the stomach, presence of air spaces, etc.

Sma11 Intestine (SI). The small intestine does not seem to remain in any "standard position" except the ends which are relatively fixed. Thus the small incestine is to be regarded as occupying a volume within which it is free to move. No attempt to determine a specific configuration is made here, and thus the wall and contents are not distinguished for estimate of photon dose. The total mass is $29.9 \mathrm{~g}$, and has a corresponding volume of about $29.7 \mathrm{~cm}^{3}$. This volume, which lies in the abdominal region, is a section of a circular cylinder given by 


$$
\begin{gathered}
X^{2}+(Y+1.2)^{2} \leq(4.0)^{2} \\
-1.45 \leq Y \leq 1.5 \\
4.7 \leq Z \leq 6.7
\end{gathered}
$$

but the portion of the large intestine within this region is excluded.

Upper Large Intestine (ULI). The upper large intestine consists of an ascending colon and a transverse colon. The ascending colon is defined by the inequalities

$$
\begin{gathered}
(X+2.9)^{2}+(Y+0.6)^{2} \leq(0.85)^{2} \\
(X+2.9)^{2}+(Y+0.6)^{2} \geq(0.45)^{2} \\
3.4 \leq Z \leq 5.7 .
\end{gathered}
$$

The wall has a total volume of $3.75 \mathrm{~cm}$ and mass of $3.78 \mathrm{~g}$. The inequalities

$$
\begin{gathered}
(X+2.9)^{2}+(Y+0.6)^{2} \leq(0.45)^{2} \\
3.4 \leq Z \leq 5.7
\end{gathered}
$$

define the contents of the ascending colon. The volume is $1.46 \mathrm{~cm}^{3}$, and the mass is $1.47 \mathrm{~g}$. The thickness of the wall is $0.4 \mathrm{~cm}$.

The transverse colon has an elliptical cross-section and is defined by:

$$
\begin{gathered}
\left(\frac{Y+0.6}{0.85}\right)^{2}+\left(\frac{z-6.2}{0.5}\right)^{2} \leq 1 \\
\left(\frac{Y+0.6}{0.65}\right)^{2}+\left(\frac{z-6.2}{0.3}\right)^{2} \geq 1 \\
-3.6 \leq x \leq 3.6 .
\end{gathered}
$$


The volume of the wall is $5.2 \mathrm{~cm}^{3}$, and the mass is $5.24 \mathrm{~g}$. By this model the thickness is about $0.2 \mathrm{~cm}$. The contents are specified by

$$
\begin{gathered}
\left(\frac{Y+0.6}{0.65}\right)^{2}+\left(\frac{z-6.2}{0.3}\right)^{2} \leq 1 \\
-3.6 \leq x \leq 3.6 .
\end{gathered}
$$

The volume is $4.4 \mathrm{~cm}^{3}$, and the mass is $4.44 \mathrm{~g}$.

Lower Large Intestine (LLI). The lower large intestine consists of a descending colon and a sigmoid colon. The descending colon is described by the inequalities

$$
\begin{gathered}
\left(\frac{X-X_{0}}{0.7}\right)^{2}+\left(\frac{Y-Y_{O}}{0.8}\right)^{2} \leq 1 \\
\left(\frac{X-X_{O}}{0.48}\right)^{2}+\left(\frac{Y-Y_{O}}{0.38}\right)^{2} \geq 1 \\
2.8 \leq Z \leq 5.7
\end{gathered}
$$

where

$$
\begin{gathered}
X_{0}=2.9+\frac{0.1(Z-5.7)}{2.9} \\
Y_{0}=\frac{0.6(2.8-Z)}{2.9}
\end{gathered}
$$

The descending colon has a volume of $3.44 \mathrm{~cm}^{3}$ and a mass of $3.46 \mathrm{~g}$. The thickness of the wall varies between $0.22 \mathrm{~cm}$ and $0.42 \mathrm{~cm}$.

The sigmoid colon consists of portions of twn torii and is defined by the inequalities (upper portion) 


$$
\begin{gathered}
\left(\sqrt{(X-0.8)^{2}+(Z-2.8)^{2}}-2\right)^{2}+Y^{2} \leq(0.65)^{2} \\
\left(\sqrt{(X-0.8)^{2}+(Z-2.8)^{2}}-2\right)^{2}+Y^{2} \geq(0.28)^{2} \\
X \geq 0.8 \text { and } Z \leq 2.8
\end{gathered}
$$

and (lower portion)

$$
\begin{gathered}
\left(\sqrt{(X-0.8)^{2}+Z^{2}}-0.8\right)^{2}+Y^{2} \leq(0.65)^{2} \\
\left(\sqrt{(X-0.8)^{2}+Z^{2}}-0.8\right)^{2}+Y^{2} \geq(0.28)^{2} \\
X \leq 0.8 \text { and } \quad Z \geq 0 .
\end{gathered}
$$

The volume of the sigmoid colon is $4.75 \mathrm{~cm}^{3}$, and the mass is $4.79 \mathrm{~g}$. The thickness of the wall is $0.37 \mathrm{~cm}$.

The entire gastrointestinal tract is sketched in Figure 12 .

Gall Bladder. The gall bladder is defined by two concentric cylinders. A rotation and translation are then effected. The gall bladder (Figure 13) is represented by:

$$
\begin{gathered}
X_{1}=0.9076(X+0.8)+0.2388(Y+1)-0.3303(Z-7.2), \\
Y_{1}=-0.2432(X+0.8)+0.9659(Y+1)+0.0885(Z-7.2), \\
Z_{1}=0.342(X+0.8)+0.9396(Z-7.2), \\
X_{1}^{2}+Y_{1}^{2} \leq(0.5)^{2} \\
X_{1}^{2}+Y_{1}^{2} \geq(0.42)^{2} . \\
0 \leq Z \leq 3.1 .
\end{gathered}
$$




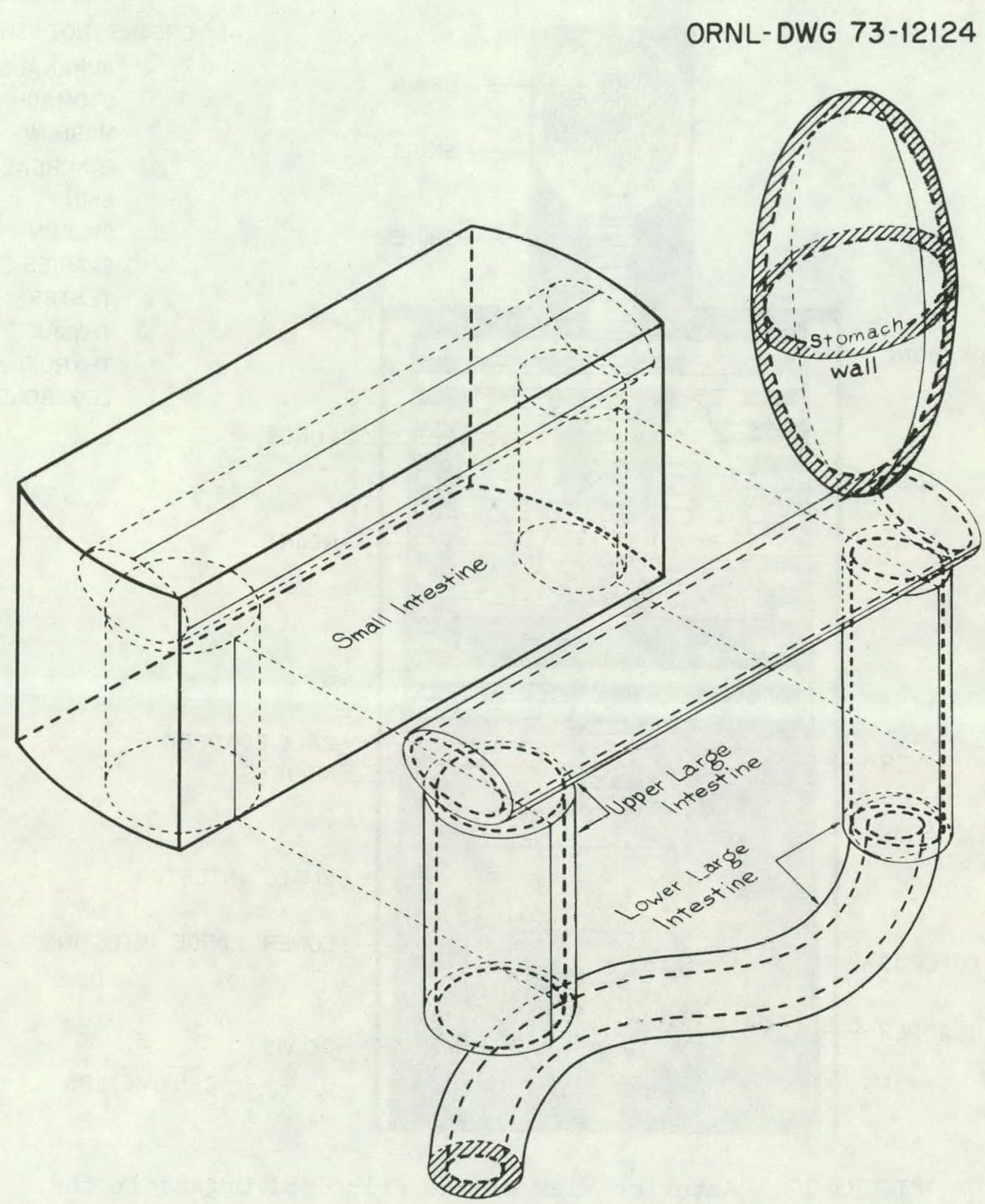

FIGURE 12. Mathematical Model for the Gastrointestinal Tract 


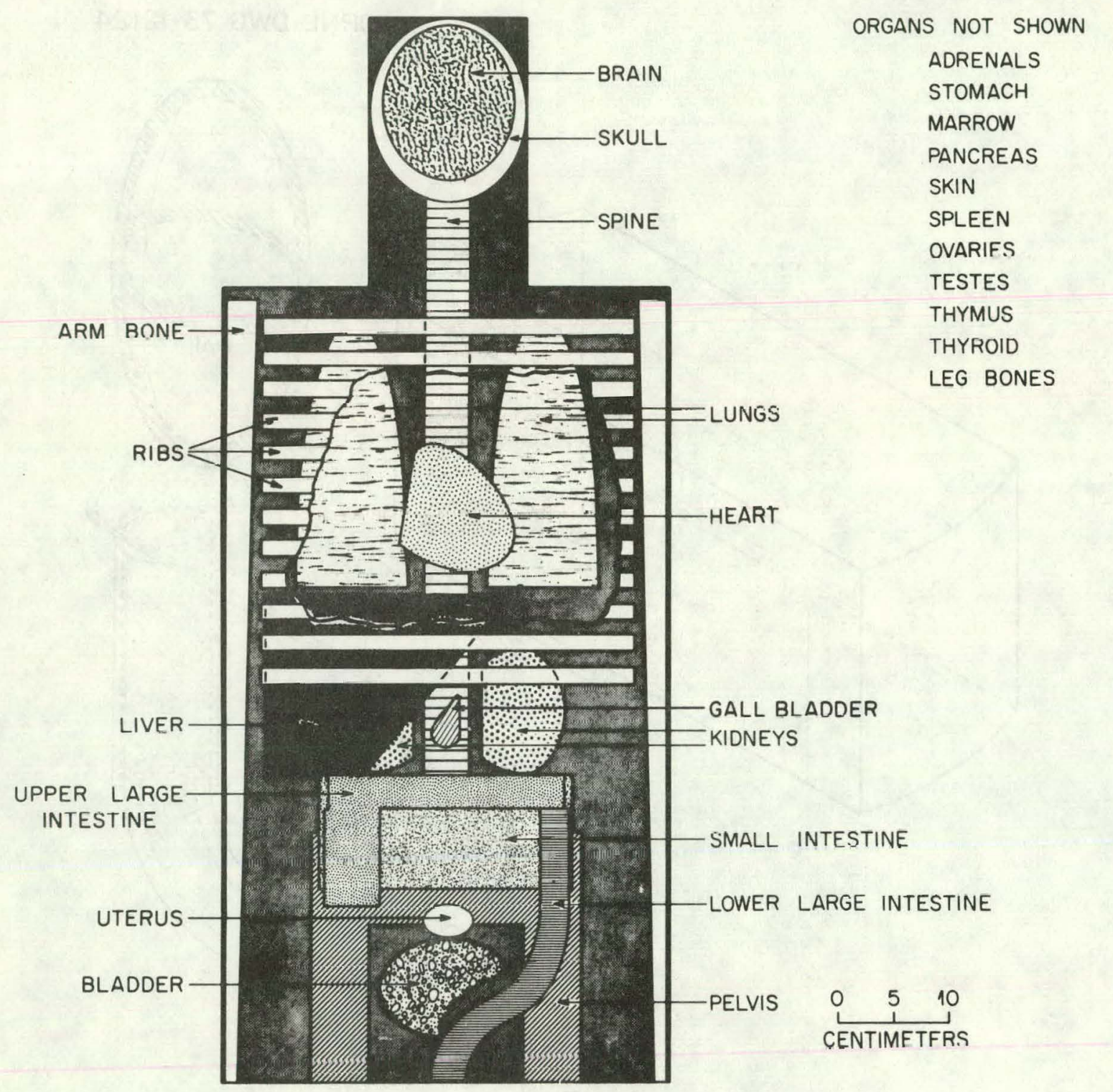

FIGURE 13. Anterior View of the Principal Organs in the Head and Trunk of the Newborn Phantom 
The volume is $0.716 \mathrm{~cm}^{3}$, and the mass is $0.722 \mathrm{~g}$. The contents have a volume of $1.718 \mathrm{~cm}^{3}$ and a mass of $1.73 \mathrm{~g}$. This represents a moderately. full gall bladder.

Heart. The heart is half an ellipsoid capped by a hemisphere which is cut by a plane. A rotation and translation are then effected. The heart (Figure 11) is represented by:

$$
\begin{gathered}
X_{1}=0.6634(X+0.4)-0.383(Y+1)-0.6428(Z-16), \\
Y_{1}=0.5(X+0.4)+0.866(Y+1), \\
Z_{1}=0.5566(X+0.4)-0.3214(Y+1)+0.766(Z-16), \\
\left(\frac{X_{1}}{2.4}\right)^{2}+\left(\frac{Y_{1}}{1.8}\right)^{2}+\left(\frac{Z_{1}}{1.8}\right)^{2} \leq 1, \\
X_{1}^{2}+Y_{1}^{2}+Z_{1}^{2} \leq(1.8)^{2} \text { if } X_{1} \leq 0, \\
\frac{X_{1}}{1.1}+\frac{Z_{1}}{1.8} \geq-1 \text { if } \quad X_{1} \leq 0 .
\end{gathered}
$$

It has a volume of $25 \mathrm{~cm}^{3}$ and a mass of $25.2 \mathrm{~g}$.

Kidneys. Each kidney is an ellipsoid cut by a plane (Figure 10). The left kidney is given by

$$
\begin{gathered}
\left(\frac{X-2.1}{1.6}\right)^{2}+\left(\frac{Y-3.2}{1.0}\right)^{2}+\left(\frac{Z-8.2}{1.5}\right)^{2} \leq 1, \\
x \geq 1 .
\end{gathered}
$$

The volume of both kidneys is $18.78 \mathrm{~cm}^{3}$ and the mass is $18.92 \mathrm{~g}$. 
Liver. The liver is defined by an elliptical cylinder cut by a plane as follows:

$$
\begin{gathered}
\left(\frac{X}{4.6}\right)^{2}+\left(\frac{Y}{4.6}\right)^{2} \leq 1, \\
\frac{X}{6.8}+\frac{Y}{10.2}-\frac{Z}{11.7} \leq-1, \\
6.7 \leq Z \leq 11.7 .
\end{gathered}
$$

Its volume is $111.89 \mathrm{~cm}^{3}$ (Figure 11) and its mass is $112.72 \mathrm{~g}$.

Lungs. Each lung is half an ellipsoid with an anterior section removed. The defining expressions for the left lung are:

$$
\begin{gathered}
\left(\frac{X-2.9}{1.7}\right)^{2}+\left(\frac{Y}{2.5}\right)^{2}+\left(\frac{Z-11.8}{8.1}\right)^{2} \leq 1, \\
11.8 \leq Z \leq 19.9 \\
\left(\frac{X-0.7}{1.7}\right)^{2}+\left(\frac{Y}{2.5}\right)^{2}+\left(\frac{Z-11.8}{8.1}\right)^{2} \geq 1 \text { if } Y<0 .
\end{gathered}
$$

The volume of both lungs is $132.3 \mathrm{~cm}^{3}$ (Figure 11) and the mass is $39.7 \mathrm{~g}$.

Ovaries. Each ovary is an ellipsoid (Figure 14). The left ovary is given by

$$
\left(\frac{X-1.5}{0.3}\right)^{2}+\left(\frac{Y}{0.2}\right)^{2}+\left(\frac{Z-4.1}{0.6}\right)^{2} \leq 1 .
$$

The volume of both ovaries is $0.3 \mathrm{~cm}^{3}$ and the mass is $0.303 \mathrm{~g}$.

Pancreas. The pancreas is half an ellipsoid with a section removed (Figure 10). It is defined by 


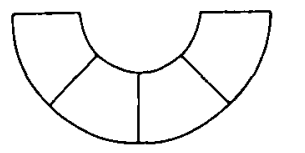

IOP VIEW

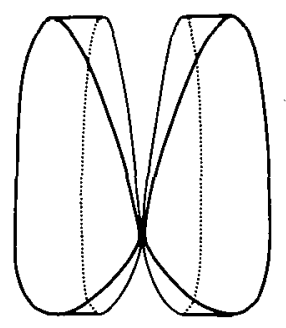

FRONT VIEW

THYROID

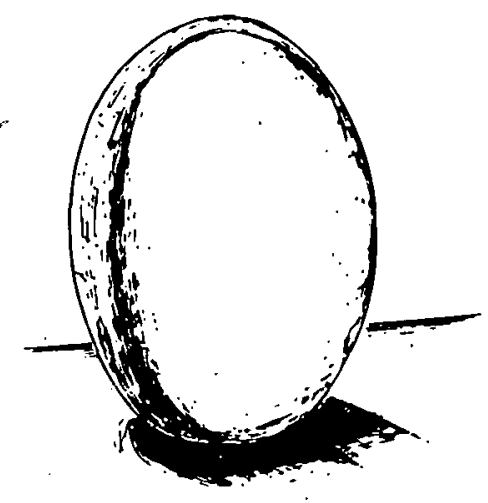

TESTES
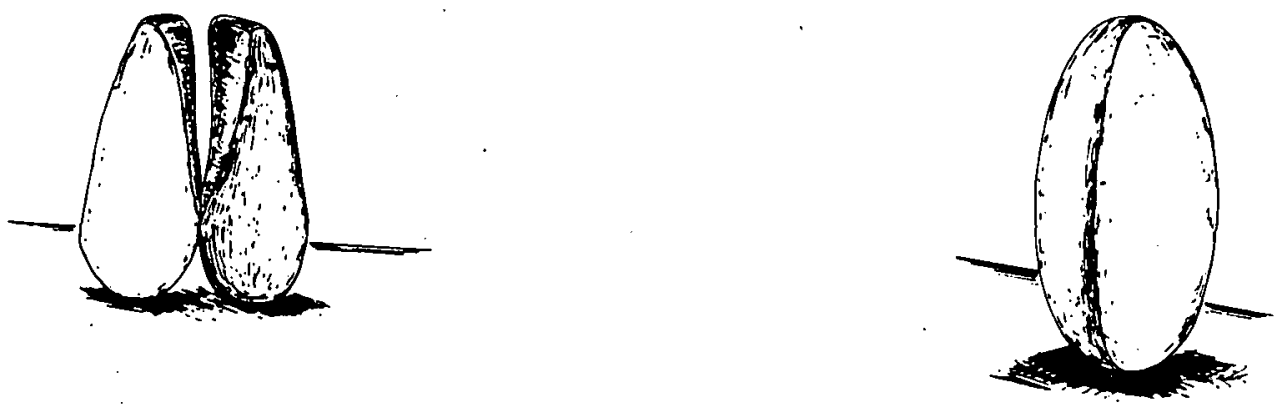

THYROID

OVARY
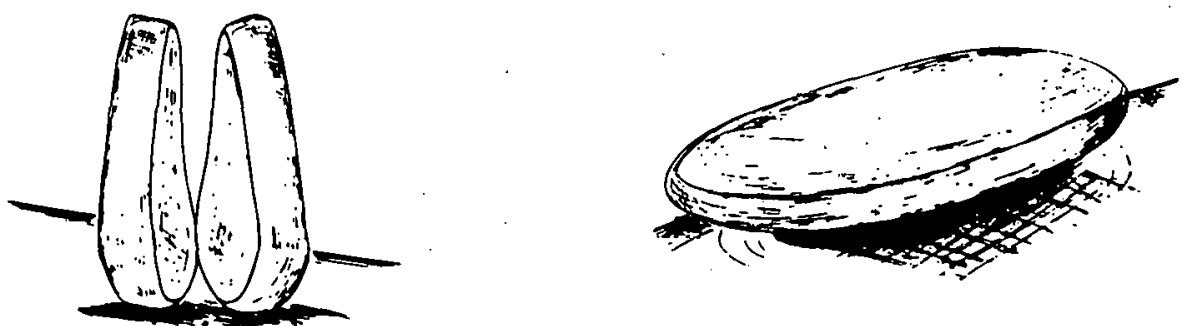

THYRSIR

THYMUS

FIGURE 14. Mathematical Models for the Thyroid, Testes, Ovaries and Thymus 


$$
\begin{gathered}
\left(\frac{X+0.5}{5}\right)^{2}+\left(\frac{Y}{0.4}\right)^{2}+\left(\frac{z-9.4}{0.9}\right)^{2} \leq 1 ; \\
x \geq-0.5, \\
Z \geq 9.4 \text { if } x \geq 0.5 .
\end{gathered}
$$

It has a volume of $2.56 \mathrm{~cm}^{3}$ and a mass of $2.58 \mathrm{~g}$.

Skin. Skin is represented as a layer of $0.13 \mathrm{~cm}$ thickness extending over the entire exterior of the phantom. Thus this corresponds lu the dermis as weil as the epıdermis. The back is the only major body area where the thickness is larger, being about double. The volume of skin is $229.3 \mathrm{~cm}^{3}$ and the mass is $231 \mathrm{~g}$.

Salivary Glands. The salivary glands consist of three pairs of glands located proximal to the mandible within the lower head section (Figure 15). These three pairs of glands are described below:

-Parotid Glands. These glands are triangular shaped and lie between the skin and mandible on the right and left sides of the head. Their volumes are described by sections of two concentric elliptical cylinders cut by an elliptical surface in the $Y-Z$ plane. The parotid glands are given by the equations as follows:

$$
\begin{gathered}
\left(\frac{Y+1.6}{1.6}\right)^{2}+\left(\frac{Z-26.2}{2.1}\right)^{2} \leq 1 \\
=1.6 \leq Y \leq 0 \\
24.1 \leq Z \leq 26.2
\end{gathered}
$$


ORNL-DWG 76-1947

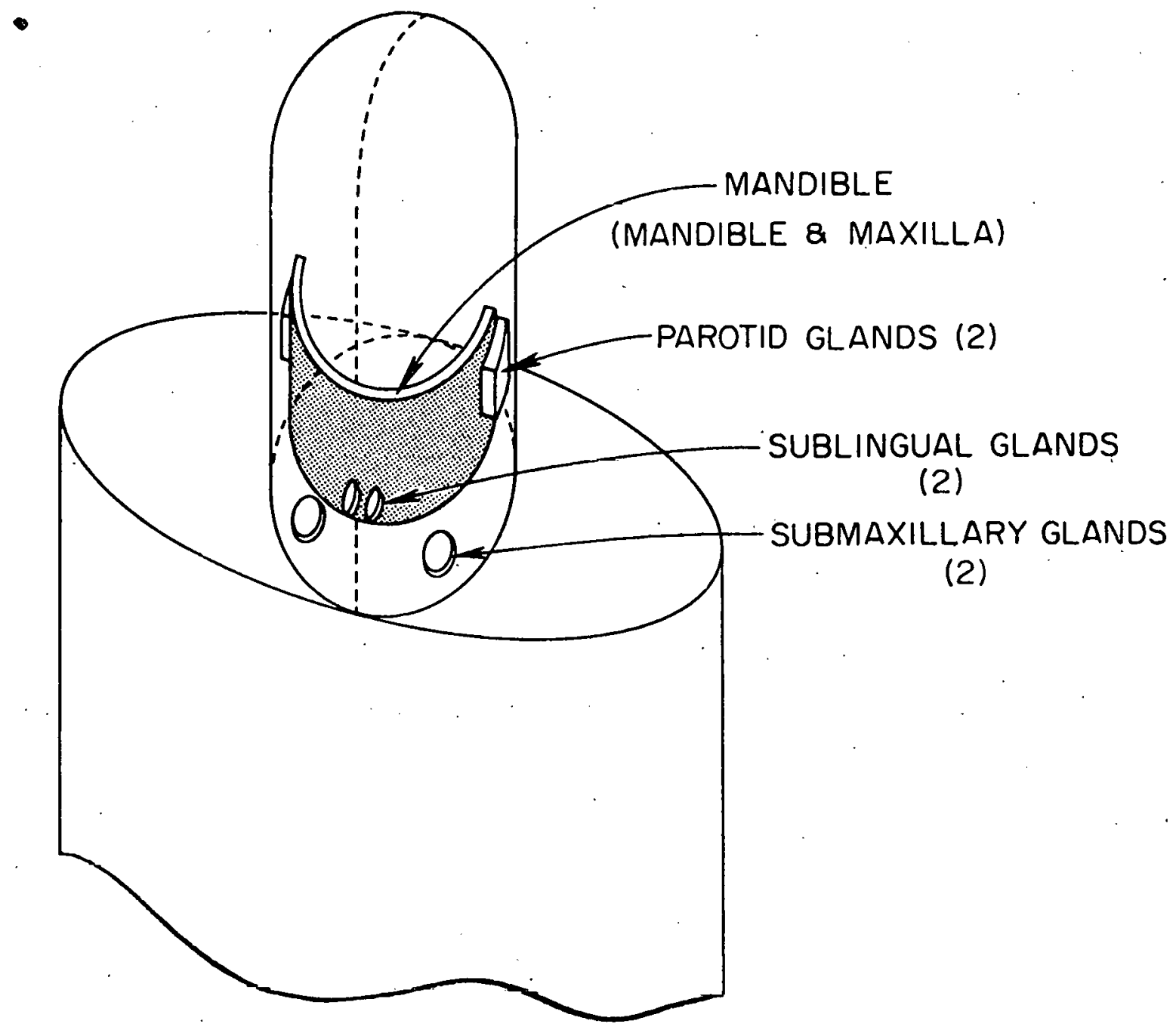

FIGURE 15. Head Section of Phantom Illustrating Approximate Location of Salivary Glands 


$$
\begin{aligned}
& \left(\frac{X}{4.47}\right)^{2}+\left(\frac{Y}{4.77}\right)^{2} \geq 1 \\
& \left(\frac{X}{5.17}\right)^{2}+\left(\frac{Y}{5.47}\right)^{2} \leq 1 .
\end{aligned}
$$

The total volume of parotid glands is $3.69 \mathrm{~cm}^{3}$ and the mass is $3.72 \mathrm{~g}$. -Submaxillary Glands. These glands are elliptical discs which are located immediately below and towards the front part of the mandible. They lie symmetrically on the right and left sides of the $x$-axis. They are described as:

$$
\left(\frac{X-2.6}{0.6}\right)^{2}+\left(\frac{Y+2.5}{0.9}\right)^{2} \leq 1
$$

and

$$
22.6 \leq z \leq 23.1
$$

the volume of both submaxillary $\mathrm{glands}$ is $1.69 \mathrm{~cm}^{3}$, and the mass is $1.7 \mathrm{~g}$. -Sublingual Glands. These glands are elliptical discs and located interior to and near the bottom of the mandible. They lie symmetrically on left and right sides of the $x$-axis. They are given by:

$$
\left(\frac{X-0.7}{0.3}\right)^{2}+\left(\frac{Y+2.8}{0.9}\right)^{2} \leq 1
$$

and

$$
23.3 \leq 2 \leq 23.8
$$

the volume of both sublingual glands is $0.84 \mathrm{~cm}^{3}$ and the mass is $0.85 \mathrm{~g}$.

Spleen. The spleen is defined by the ellipsoid 
39

$$
\left(\frac{X-3}{1.3}\right)^{2}+\left(\frac{Y-1.3}{0.7}\right)^{2}+\left(\frac{z-9.4}{2.3}\right)^{2} \leq 1
$$

and has a volume of $8.76 \mathrm{~cm}^{3}$ and a mass of $8.83 \mathrm{~g}$.

Testicles. The testicles are ellipsoid (Figure 14) which are represented by the inequalities

$$
\left(\frac{X \pm 0.4}{0.4}\right)^{2}+\left(\frac{Y+2.4}{0.5}\right)^{2}+\left(\frac{Z+0.5}{0.5}\right)^{2} \leq 1
$$

where the plus sign is used for the right testicle and the minus sign for the left. The volume of both testicles is $0.83 \mathrm{~cm}^{3}$ and the mass of $0.84 \mathrm{~g}$.

Thymus. The thymus is described by the ellipsoid:

$$
\left(\frac{x+0.3}{1.2}\right)^{2}+\left(\frac{y+3.9}{0.6}\right)^{2}+\left(\frac{z-17}{3.8}\right)^{2} \leq 1
$$

and it has a volume of $11.46 \mathrm{~cm}^{3}$ (Figure 14) and a mass of $11.54 \mathrm{~g}$.

Thyroid. The lobes of the thyroid lie between two concentric cylinders and are formed by a cutting surface (Figure 14 and Figure 16). The expressions for this organ are

$$
\begin{gathered}
X^{2}+(Y+2.2)^{2} \leq(1.2)^{2}, \\
X^{2}+(Y+2.2)^{2} \geq 1^{2}, \\
Y+2.2 \leq 0
\end{gathered}
$$




\section{SECTIONS BY THE PLANES:}

(a)

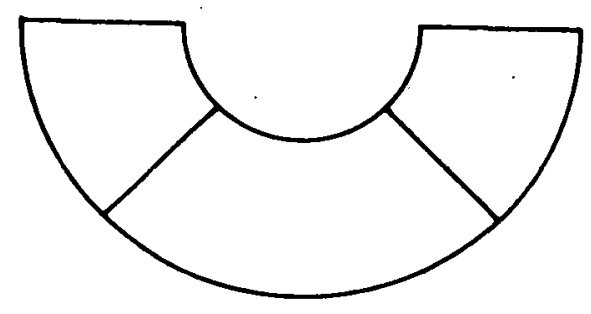

(c)

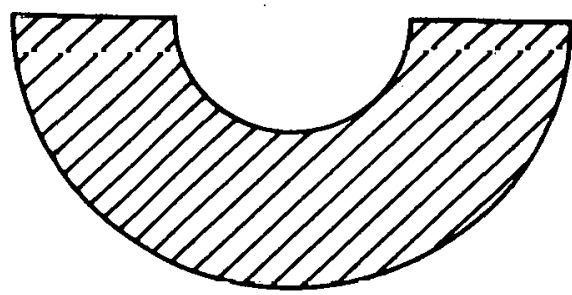

(b)
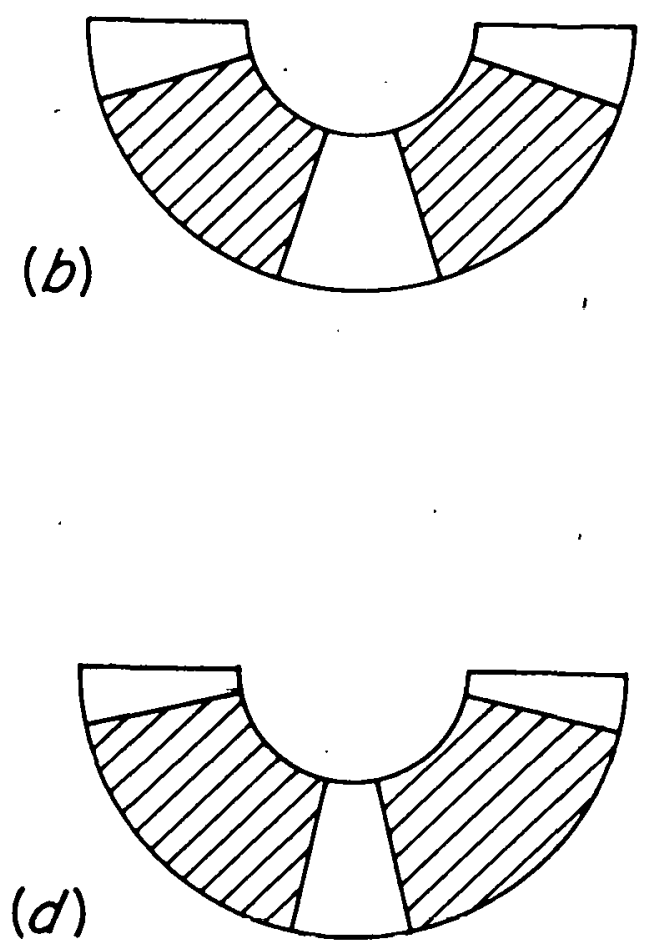
(A)
$Z=21, Z=23.1$
(B)
$z=21.21$
(C)
$z=21.52$
(D)
$Z=22.26$

FIGURE 16. Sections of the Mathematical Thyroid at Various Heights for the Children Phantoms. Shaded Areas Represent the Thyroid 


$$
\begin{gathered}
21 \leq z \leq 23.1, \\
\{(Y+2.2)-|X|\}^{2} \geq 2\left\{x^{2}+(Y+2.2)^{2}\right\} \tau^{2},
\end{gathered}
$$

in which

$$
\tau=\frac{2(\sqrt{2}-2)}{2.1}(z-21)+1 \text { for } \quad 0 \leq z-21 \leq 0.525
$$

and

$$
\tau=\frac{2(\sqrt{2}-2)}{6.3}(z-2.1)+\frac{2 \sqrt{2}-1}{3} \text { for } 0.525 \leq z .-21 \leq 2.1 \text {. }
$$

The volume is $0.96 \mathrm{~cm}^{3}$ and the mass is $0.97 \mathrm{~g}$.

Uterus. The uterus is an ellipsoid cut by a plane and is given by

$$
\begin{gathered}
\left(\frac{X}{1}\right)^{2}+\left(\frac{Y+0.3}{2.6}\right)^{2}+\left(\frac{Z-4.3}{0.3}\right)^{2} \leq 1 \\
Y \geq-1.6 .
\end{gathered}
$$

It has a volume of $2.75 \mathrm{~cm}^{3}$ (Figure 10) and a mass of $2.77 \mathrm{~g}$. 


\section{REFERENCES}

1. W. S. Snyder, M. J. Cook, E. S. Nasset, L. Karhausen, G. P. Howe11s, and I. H. Tipton, Report of the Task Group on Reference Man, ICRP Publication No. 23 (1975).

2. W. S. Snyder, M. R. Ford, and G. G. Warner, Oak Ridge National Laboratory Report ORNL-4822, 86 (1972). 
ORNL/TM-5453

INTERNAL DISTRIBUTION

1-2. Central Research Library

3. Document Reference Section

4-6. Laboratory Records Department

7. Laboratory Records, ORNL R. C.

8. ORNL Patent Office

9. Research and Technical Support Div.

10-36. Technical Information Center

37. J. A. Auxier

38. S. R. Bernard

39. M. F. Fair

40. M. R. Ford

41. F. F. Haywood

42. J. L. Hwang

\author{
43. D. G. Jacobs \\ 44. T. D. Jones \\ 45. G. D. Kerr \\ 46. S. K. Penny \\ 47-71. J. W. Poston \\ 72. C. R. Richmond \\ 73-87. R. L. Shoup \\ 88. W. S. Snyder \\ 89. P. S. Stansbury \\ 90. S. B. Watson \\ 91. G. G. Warner \\ 92. H. A. Wright
}

\section{EXTERNAL DISTRIBUTION}

93. S. James Adelstein, Shields Warren Radiology Lab.; 50 Binney St., Boston, Mass. 02115.

94. Monte Blau, Roswell Park Memorial Institute, Dept. of Nuclear Medicine, 666 Elm Street, Buffalo, NY 14203.

95. Mones Berman, National Cancer Institute of Health, Building 10, Room 4B-56, Bethesda, MD . 20014.

96. C. E. Carter, Division of Biomedical and Enviromental Research, ERDA, Washington, D.C. 20545.

97. R. J. Cloutier, ORAU, Oak Ridge, Tennessee 37830.

98. R. D. Cooper, Division of Biomedical and Environmental Research, ERDA, Washington, D.C. 20545.

99. Dr. George Cowper, Atomic Energy of Canada, Ltd.; Chalk River, Ontario, Canada.

100. L. J. Dcal, Asst. Director of Safety Protection, Division of Operational Safety, ERDA, Washington, D.C. 20545.

101. L. T. Dillman, Department of Physics, Ohio Wesleyan University, Delaware, Ohio 43015.

102. Mrs. Judy Glus; The Society of Nurlear Medicine, 475 Park Avenue South, New York, NY 10016.

103. Alexander Gottschalk, Department of Radiology, Yale University School of Medicine, 333 Cedar Street, New Haven, CT 06510.

104. R. J. Hart, Manager, Oak Ridge Operations.

105. Dr. Marguerite T. Hays, 151, Director of Medical Research Services, Veterans Administration, Department of Medicine and Surgery, Washington, D.C. 20420. 


\section{EXTERNAL DISTRIBUTION（CON'T）}

106. R. Eugene Johnston, Dept. of Radiology, N.C.M.H., Division of Nuclear Medicine, University of North Carolina, Chapel Hill, N.C. 27514.

107. Dr. James Kereiakes, E555 Medical Sciences Building, University of Cincinnati, Cincinnati, Ohio 45267.

108. Katherine A. Lathrop, Franklin McLean Memorial Research Institute, The Univ. of Chicago, 950 East 59th St., Box 420, Chicago, Ill. 60637.

109. Robert Loevinger, Radiation Physics Bldg., Room C210, National Bureau of Standards, Washington, D.C. 20234.

110. John G. McAfee, Division of Nuclear Medicine, Upstate Medical Center, 750 East Adams Street, Syracuse, NY 132lo,

111. R. T. MeLaughlin, Director, Radiation Physics Division, Health and Safety Irahoratiny, ERD $\Lambda$, New Yurk Operut1ons Ut't'ice, 376 Hudson Blreet, New York, NY 10014.

112. K. Z. Morgan, School of Nuclear Engineering, Georgia Institute of Technology, Atlanta, Georgia 30332.

113. Dr. Peter Yaras, Bureau of Radiological Health, Food and Drug Administration, 12720 Twirbrook Parkway, Rockville, MD 20852.

114. E. James Potchen, Office of the Dean, John Hopkins Medical School, 725 N. Wolfe Street, Baltimore, MD 21205.

115. Robert H. Rohrer, Ph.D., Dept. of Physics, Emory University, Atlanta, Georgia 30322.

116. Dr. Marvin Rosenstein, Bureau of Radiological Health, Food and Drug Administration, 12720 Twinbrook Parkway, Rockville, MD 20852.

117. W. W. Schroebel, Division of Biomedical and Environmental Reocarch, ITDA, Wushingtón, D.C. 20545.

118. Dr. Edward M. Smith, Executive Dir., MIRD Committee, 404 Church Ave., Suite 15, Maryville, TN 37801.

119. Dr. I. V. Spencer, Center on Radiation Research, National Bureau Standards, Washington, N.r. 2023l.

120. Dr. Betsy J. Stover, Division of Health Affairs, Department of Pharmacology, Swing Building, University of North Carolina, Chapel Hill, North Carolina 27514.

121. Dr. Roy L. Thompson, Biology Dept., Pacific Northwest Laboratories, Bettelle, Rishlend, Washingtom 99352.

122. John C. Villforth, Bureau of Radiological Health, Food and Drug Administration, 12780 Twinurook Farkway, Rockville, MD 21205.

123. Robert W. Wood, Division of Biomedical and Environmental Research, Radiological Physics and Instrumentation Branch, ERDA, Washington, D.C. 20545. 